\title{
The Impact of Intraspecies Variability on Growth Rate and Cellular Metabolic Activity of Bacteria Exposed to Rotating Magnetic Field
}

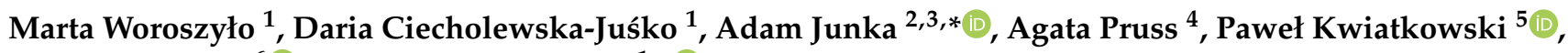 \\ Marcin Wardach ${ }^{6}$ (D) and Karol Fijałkowski ${ }^{1, *(D)}$
}

1 Department of Microbiology and Biotechnology, Faculty of Biotechnology and Animal Husbandry, West Pomeranian University of Technology in Szczecin, Piastów 45, 70-311 Szczecin, Poland; marta.woroszylo@zut.edu.pl (M.W.); daria.ciecholewska@zut.edu.pl (D.C.-J.)

2 Department of Pharmaceutical Microbiology and Parasitology, Faculty of Pharmacy, Medical University of Wroclaw, Borowska 211a, 50-534 Wrocław, Poland

3 Laboratory of Microbiology, Łukasiewicz Research Network-PORT Polish Center for Technology Development, 54-066 Wrocław, Poland

4 Department of Laboratory Medicine, Pomeranian Medical University in Szczecin, Powstańców Wielkopolskich 72, 70-111 Szczecin, Poland; agata.pruss@pum.edu.pl

5 Department of Diagnostic Immunology, Pomeranian Medical University in Szczecin, Powstańców Wielkopolskich 72, 70-111 Szczecin, Poland; pawel.kwiatkowski@pum.edu.pl

check for updates

Citation: Woroszyło, M.; Ciecholewska-Juśko, D.; Junka, A.; Pruss, A.; Kwiatkowski, P.; Wardach, M.; Fijałkowski, K. The Impact of Intraspecies Variability on Growth Rate and Cellular Metabolic Activity of Bacteria Exposed to Rotating Magnetic Field. Pathogens 2021, 10, 1427. https://doi.org/10.3390/ pathogens10111427

Academic Editor: Peter N. Lipke

Received: 13 October 2021

Accepted: 29 October 2021

Published: 4 November 2021

Publisher's Note: MDPI stays neutral with regard to jurisdictional claims in published maps and institutional affiliations.

Copyright: (C) 2021 by the authors Licensee MDPI, Basel, Switzerland. This article is an open access article distributed under the terms and conditions of the Creative Commons Attribution (CC BY) license (https:// creativecommons.org/licenses/by/ $4.0 /)$.
6 Faculty of Electrical Engineering, West Pomeranian University of Technology in Szczecin, Sikorskiego 37, 70-313 Szczecin, Poland; marcin.wardach@zut.edu.pl

* Correspondence: adam.junka@umed.wroc.pl (A.J.); karol.fijalkowski@zut.edu.pl (K.F.); Tel.: +48-88-922-9341 (A.J.); +48-91-449-6714 (K.F.)

Abstract: Majority of research on the influence of magnetic fields on microorganisms has been carried out with the use of different species or different groups of microorganisms, but not with the use of different strains belonging to one species. The purpose of the present study was to assess the effect of rotating magnetic fields (RMF) of 5 and $50 \mathrm{~Hz}$ on the growth and cellular metabolic activity of eight species of bacteria: Staphylococcus aureus, Pseudomonas aeruginosa, Proteus mirabilis, Klebsiella pneumoniae, Enterococcus faecalis, Enterobacter cloacae, Moraxella catarrhalis, and Bacillus cereus. However, contrary to the research conducted so far, each species was represented by at least four different strains. Moreover, an additional group of $S$. aureus belonging to a single clonal type but representing different biotypes was also included in the experiment. The results showed a varied influence of RMF on growth dynamics and cellular metabolic activity, diversified to the greatest extent in dependence on the bacterial strain exposed to the RMF and to a lesser extent in dependence on the frequency of the generated magnetic field. It was found that, with regard to the exposed strain of the same species, the effect exerted by the RMF may be positive (i.e., manifests as the increase in the growth rate or/and cellular metabolic activity) or negative (i.e., manifests as a reduction of both aforementioned features) or none. Even when one clonal type of S. aureus was used, the results of RMF exposure also varied (although the degree of differentiation was lower than for strains representing different clones). Therefore, the research has proven that, apart from the previously described factors related primarily to the physical parameters of the magnetic field, one of the key parameters affecting the final result of its influence is the bacterial intraspecies variability.

Keywords: cellular metabolic activity; clone; growth dynamics; rotating magnetic field; species; strain; viability

\section{Introduction}

The ability to modify microorganisms' behavior, understood as the level of metabolic activity or rate of cellular division, is pivotal from the point of view of biotechnology and 
medicine, as it allows for the increase in the yield of microbiologically derived products or the decrease in the symptoms of infection. The measures applied for such modifications include a vast spectrum of agents/stimuli, which can be chemical or physical. Belonging to the latter category, the electromagnetic field (EMF) can be viewed as a combination of an electric field (EF) and a magnetic field (MF). The first studies on the influence of magnetic fields (MFs) on organisms started at the end of the 19th century. This line of investigation was intensified in subsequent decades, mostly fueled by a growing interest in the impact of fields generated by electric and telecommunication networks on the health and behavior of humans and such animals as bees or birds [1]. In turn, the first reports on the use of MFs to affect microbial growth were released more than 60 years ago [2], while data on the impact of MFs on the viability of microorganisms were presented already in the late 1960s [3,4]. Since that time, numerous studies have been published on the influence of different types of MFs on various parameters associated with microorganisms (Table 1).

Table 1. Review of works showing the influence of magnetic fields on the viability, growth rate, and cellular metabolic activity of various species and strains of bacteria.

\begin{tabular}{ccccccc}
\hline Bacterial Species & Intensity & Frequency & Current & $\begin{array}{c}\text { Time of } \\
\text { Exposure }\end{array}$ & Field & $\begin{array}{c}\text { Biological Effect/Author } \\
\text { Conclusions }\end{array}$ \\
\hline $\begin{array}{c}\text { S. aureus } \\
\text { E. coli }\end{array}$ & $0.5-4 \mathrm{~T}$ & - & - & $30-120 \mathrm{~min}$ & SMF & No influence on growth. \\
\hline $\begin{array}{c}\text { S. aureus* } \\
\begin{array}{c}\text { S. mutans } \\
\text { E. coli }\end{array}\end{array}$ & $\begin{array}{c}\text { No, } \\
100 \mathrm{mT}\end{array}$ & - & - & Uncertain & SMF & $\begin{array}{c}\text { Ferrite magnet caused } \\
\text { on the growth of S. mutans and S. } \\
\text { aureus when cultured under } \\
\text { anaerobic conditions. No growth } \\
\text { effects were detected on E. coli } \\
\text { cultures. }\end{array}$ \\
\hline
\end{tabular}

\begin{tabular}{|c|c|c|c|c|c|c|c|}
\hline $\begin{array}{l}\text { S. aureus FA } 812 \\
\text { E. coli strain } \mathrm{K} 12 \\
\text { L. adecarboxylata } \\
2177\end{array}$ & $10 \mathrm{mT}$ & $50 \mathrm{~Hz}$ & - & $<30 \min$ & LF-EMF & $\begin{array}{l}\text { Decrease in the cell viability and } \\
\text { inhibitory effect on the growth rate. }\end{array}$ & [7] \\
\hline E. coli $*$ & $300 \mathrm{mT}$ & - & - & Up to $50 \mathrm{~h}$ & SMF & $\begin{array}{l}\text { In the standard medium (LB), no } \\
\text { differences between the control and } \\
\text { exposed culture were observed. In } \\
\text { the modified medium (LB + } \\
\text { glutamic acid) after } 25 \mathrm{~h} \text { of } \\
\text { cultivation, significant growth } \\
\text { stimulation under field exposure } \\
\text { occurred in comparison with the } \\
\text { control. }\end{array}$ & [8] \\
\hline
\end{tabular}

\begin{tabular}{|c|c|c|c|c|c|c|c|}
\hline $\begin{array}{c}\text { S. aureus } \\
\text { (38 strains) } \\
\text { E. coli ( } 38 \text { strains) } \\
\text { Strains were } \\
\text { analyzed } \\
\text { as a whole group }\end{array}$ & - & $50 \mathrm{~Hz}$ & - & $30-150 \mathrm{~min}$ & SEF & $\begin{array}{l}\text { Inhibitory effect on the growth of } \\
\text { Gram-negative E. coli was greater } \\
\text { than Gram-positive S. aureus. }\end{array}$ & [9] \\
\hline $\begin{array}{c}\text { S. aureus FA } 812 \\
\text { R. erythropolis } \\
\text { E. coli strain K12 } \\
\text { L. adecarboxylata } \\
2177 \\
\text { P. denitrificans CCM } \\
982 \\
\text { S. paucimobilis }\end{array}$ & $10 \mathrm{mT}$ & $50 \mathrm{~Hz}$ & - & $24 \mathrm{~min}$ & MF & $\begin{array}{l}\text { The MF caused a decrease in optical } \\
\text { densities of bacterial cultures; the } \\
\text { effect was higher for rodlike } \\
\text { bacteria. }\end{array}$ & [10] \\
\hline $\begin{array}{c}\text { S. aureus ATCC } \\
49230\end{array}$ & $5 \mathrm{mT}$ & $20 \mathrm{~Hz}$ & $1.2 \mathrm{~A}$ & $24 \mathrm{~h}$ & LF-EMF & $\begin{array}{l}\text { Decreased number of cells by } 37.3 \% \\
\text { for electric field }\left(E=588 \mathrm{mV} \cdot \mathrm{cm}^{-1}\right) \\
\text { was observed. }\end{array}$ & [11] \\
\hline
\end{tabular}


Table 1. Cont.

\begin{tabular}{|c|c|c|c|c|c|c|c|}
\hline Bacterial Species & Intensity & Frequency & Current & $\begin{array}{l}\text { Time of } \\
\text { Exposure }\end{array}$ & Field & $\begin{array}{l}\text { Biological Effect/Author } \\
\text { Conclusions }\end{array}$ & References \\
\hline $\begin{array}{c}\text { S. aureus } 52 / 03 \\
\text { B. circulans B } 01115 \\
\text { M. luteus B } 01072 \\
\text { P. fluorescens B } 01102 \\
\text { S. enteritidis serovar } \\
\text { Enteritidis } 359 / 07 \\
\text { S. marcescens } \\
\quad 15 / 2 / 7 / 2 \\
\text { E. coli ATCC } 35218\end{array}$ & $\begin{array}{l}477 \mathrm{mT} \\
12 \mathrm{mT} \\
2.8 \mathrm{mT}\end{array}$ & - & - & Up to $24 \mathrm{~h}$ & H-SMF & No influence on growth. & [12] \\
\hline $\begin{array}{c}\text { S. epidermidis ATCC } \\
12228 \\
\text { S. aureus ATCC } 25923 \\
\text { E. faecalis ATCC } \\
29212 \\
\text { E. coli ATCC } 25922 \\
\text { K. pneumoniae ATCC } \\
4352 \\
\text { P. aeruginosa ATCC } \\
27853 \\
\end{array}$ & $0.5 \mathrm{mT}$ & $50 \mathrm{~Hz}$ & - & $6 \mathrm{~h}$ & ELF-EMF & Inhibitory effect on growth rate. & [13] \\
\hline $\begin{array}{l}\text { S. epidermidis ATCC } \\
35984 \\
\text { E. coli ATCC } 25922\end{array}$ & $100 \mathrm{mT}$ & - & - & Up to $4 \mathrm{~h}$ & MI-SMF & Inhibitory effect on growth. & [14] \\
\hline $\begin{array}{c}\text { E. coli (MG1655, MG } \\
\text { 1655rpoS:kan mutant, } \\
\text { DH5 } \alpha \text { with } \\
\text { pRPO22oBTer }) \\
\text { P. putida Dc27 }\end{array}$ & $5-50 \mathrm{mT}$ & - & - & Up to $4 \mathrm{~h}$ & LD-SMF & Inhibitory effect on growth. & [15] \\
\hline $\begin{array}{l}\text { E. coli ATCC } 25922 \\
\text { P. aeruginosa ATCC } \\
\quad 27853\end{array}$ & $2 \mathrm{mT}$ & $50 \mathrm{~Hz}$ & - & $4,6,8 \mathrm{~h}$ & ELF-EMF & $\begin{array}{l}\text { No remarkable differences were } \\
\text { found in the rate of bacteria growth } \\
\text { comparing exposed groups with } \\
\text { control groups. }\end{array}$ & [16] \\
\hline $\begin{array}{l}\text { S. aureus ATCC } 43300 \\
\text { E. coli ATCC } 8739\end{array}$ & $22-34 \mathrm{mT}$ & $1-50 \mathrm{~Hz}$ & - & $60 \mathrm{~min}$ & RMF & $\begin{array}{l}\text { Stimulation of the growth dynamics } \\
\text { and cell metabolic activity. Higher } \\
\text { proliferation rate and cell metabolic } \\
\text { activity were found for } E \text {. coli. }\end{array}$ & [17] \\
\hline $\begin{array}{l}\text { S. aureus FRI } 913 \\
\text { S. aureus ATCC } 25923 \\
\text { S. aureus ATCC } 43300 \\
\text { E. coli O157:H7 } \\
\text { (two strains) } \\
\text { E. coli E68II/0141 }\end{array}$ & $30 \mathrm{mT}$ & $50 \mathrm{~Hz}$ & - & $150 \mathrm{~min}$ & RMF & $\begin{array}{l}\text { Stimulatory effect on the growth } \\
\text { and metabolic activity of E. coli and } \\
\text { S. aureus. }\end{array}$ & [18] \\
\hline $\begin{array}{l}\text { S. aureus ATCC } 6538 \\
\text { E. coli } \mathrm{O} 157: \mathrm{H} 7\end{array}$ & $2-4 \mathrm{mT}$ & $\begin{array}{l}20,40,50 \\
\mathrm{~Hz}\end{array}$ & - & $1-6 \mathrm{~h}$ & ELF-EMF & $\begin{array}{l}\text { Inhibitory effect on the growth rate } \\
\text { in exposed cultures. }\end{array}$ & [19] \\
\hline $\begin{array}{c}\text { S. aureus ATCC } 43300 \\
\text { S. mutans ATCC } \\
35668 \\
\text { S. xylosus ATCC } \\
29971 \\
\text { E. coli ATCC } 8739 \\
\text { A. baumannii ATCC } \\
19606 \\
\text { P. aeruginosa ATCC } \\
10145 \\
\text { S. marcescens ATCC } \\
274 \\
\text { C. sakazakii ATCC } \\
29544 \\
\text { K. oxytoca PCM } 2202\end{array}$ & $25-34 \mathrm{mT}$ & $5-50 \mathrm{~Hz}$ & - & $60 \mathrm{~min}$ & RMF & $\begin{array}{l}\text { Increase in the growth and } \\
\text { metabolic activity except for } A \text {. } \\
\text { baumannii and P. aeruginosa. }\end{array}$ & [20] \\
\hline
\end{tabular}


Table 1. Cont.

\begin{tabular}{|c|c|c|c|c|c|c|c|}
\hline Bacterial Species & Intensity & Frequency & Current & $\begin{array}{l}\text { Time of } \\
\text { Exposure }\end{array}$ & Field & $\begin{array}{l}\text { Biological Effect/Author } \\
\text { Conclusions }\end{array}$ & References \\
\hline $\begin{array}{l}\text { S. aureus ATCC } \\
25923 \\
\text { S. epidermidis ATCC } \\
14990 \\
\text { S. marcescens ATCC } \\
264 \\
\text { E. coli ATCC } 11303\end{array}$ & $250 \mu \mathrm{T}$ & $6-25 \mathrm{~Hz}$ & - & $12 \mathrm{~h}$ & ELF-EM & $\begin{array}{l}\text { Increased growth rate of } S \text {. } \\
\text { epidermidis, } S \text {. aureus, and } E \text {. coli, } \\
\text { inhibitory effect on the growth rate } \\
\text { of } S . \text { marcescens. }\end{array}$ & [21] \\
\hline $\begin{array}{l}\text { E. coli (wild strains) } \\
\text { E. coli ATCC } 25922\end{array}$ & $2-20 \mathrm{mT}$ & - & - & $\begin{array}{l}0,15,30 \\
45,60,75 \\
90 \mathrm{~min}\end{array}$ & SMF & $\begin{array}{l}\text { Inhibitory effect on the growth rate } \\
\text { in exposed cultures at } 18 \text { and } 20 \mathrm{mT} \text {. }\end{array}$ & [22] \\
\hline $\begin{array}{c}\text { S. aureus ATCC } \\
29213 \\
\text { S. epidermidis } \\
\text { ATCC } 25923 \\
\text { P. aeruginosa ATCC } \\
27853\end{array}$ & & $\begin{array}{l}900 / 1800 \\
\mathrm{MHz}\end{array}$ & - & $12 \mathrm{~h}$ & HF-EMF & $\begin{array}{l}\text { Exposure of } \text { S. epidermidis and } \\
\text { S. aureus to EMF decreased bacterial } \\
\text { growth, except for } S \text {. aureus at } \\
900 \mathrm{MHz} \text { at } 12 \mathrm{~h} \text {. Exposure of } \\
\text { P. aeruginosa to EMF at } 900 \mathrm{MHz} \\
\text { reduced growth rate, while } \\
1800 \mathrm{MHz} \text { had insignificant effect. }\end{array}$ & [23] \\
\hline $\begin{array}{c}\text { S. aureus ATCC } \\
43300 \\
\text { E. faecalis ATCC } \\
29212 \\
\text { S. mutans ATCC } \\
35668 \\
\text { E. coli ATCC } 8739 \\
\text { S. marcescens ATCC } \\
274 \\
\text { K. oxytoca PCM } \\
2202\end{array}$ & up to $18 \mathrm{mT}$ & $50 \mathrm{~Hz}$ & - & $8 \mathrm{~h}$ & RMF & $\begin{array}{c}\text { Increased growth and metabolic } \\
\text { activity of Gram-positive bacteria } \\
\text { (up to 25\%) and inhibited } \\
\text { proliferation of Gram-negative } \\
\text { bacteria (up to } 17 \% \text { ) (with the } \\
\text { exception of S. marcescens, no } \\
\text { statistical differences were } \\
\text { observed). }\end{array}$ & [24] \\
\hline $\begin{array}{l}\text { S. aureus 155554A } \\
\text { S. epidermidis } \\
155556 \mathrm{~A} \\
\text { E. coli } 155065 \mathrm{~A} \\
\text { P. aeruginosa } \\
155250 \mathrm{~A}\end{array}$ & $\begin{array}{l}0.3-0.5 \mathrm{mT} \\
7.5 \mathrm{mT} \\
0.5 \mathrm{mT} \\
0.05-0.5 \mathrm{mT}\end{array}$ & - & - & $24-36 \mathrm{~h}$ & $\begin{array}{l}\text { B-MF; } \\
\text { RM-MF; } \\
\text { U-MF; } \\
\text { O-MF }\end{array}$ & $\begin{array}{l}\text { Different MFs affect the growth } \\
\text { pattern of bacteria differently, } \\
\text { depending on the bacterial species. }\end{array}$ & [25] \\
\hline
\end{tabular}

B-MF-bar magnetic field, ELF-EMF—extremely low-frequency electromagnetic field, HF-EMF—high-frequency electromagnetic field, H-SMF-homogeneous static magnetic field, I-SMF-inhomogeneous static magnetic field, LD-SMF-low-density static magnetic field, LF-EMF—low-frequency electromagnetic field, MF—magnetic field, MI-SMF—-moderate-intensity static magnetic field, O-MF—oscillating magnetic field, SEF—static electric field, SMF—static magnetic field, RMF—rotating magnetic field, RM-MF—round-magnets magnetic field, U-MF-uniform magnetic field. "*"-information regarding the strain was not available. A. baumannii-Acinetobacter baumannii, $B$. circulans-Bacillus circulans, C. sakazakii-Cronobacter sakazakii, E. coli-Escherichia coli, E. faecalis-Enterococcus faecalis, K. oxytoca-Klebsiella oxytoca, K. pneumoniae-Klebsiella pneumoniae, L. adecarboxylata-Leclercia adecarboxylata, M. luteus-Micrococcus luteus, P. aeruginosaPseudomonas aeruginosa, P. denitrificans-Pseudomonas denitrificans, P. fluorescens-Pseudomonas fluorescens, P. putida-Pseudomonas putida, $R$. erythropolis-Rhodococcus erythropolis, S. aureus-Staphylococcus aureus, S. enteritidis-Salmonella enteritidis, S. epidermidis-Staphylococcus epidermidis, S. marcescens-Serratia marcescens, S. mutans_Streptococcus mutans, S. paucimobilis—Sphingomonas paucimobilis, S. xylosusStaphylococcus xylosus.

For a long time, the use of bacteria, as models of low complexity, to examine cellular replies to MFs was thought to enable reduction of errors associated with the interpretation of experimental results. To make the mechanisms exerted by MFs even more understandable, single-model reference microorganisms, well characterized by genetic markers, are usually used. In spite of this approach, the data presented in the literature on the subject in question are often conflicting, and the mechanisms of MF's biological activity are still not elucidated (Table 1). As an example, some authors reported the antibacterial effect of MFs [7,10,26,27], while others suggested a lack of any significant impact of MFs on microbial growth [12,28], biochemical activity [5], or bacterial adhesion [29]. In turn, other research teams demonstrated a stimulating effect of MFs on microbial cell growth and cell viability [30-32]. Such contradictory results have led to the recognition of the fact that MFs may exert a whole spectrum of biological effects (from none/absence of significant effects through inhibitory/negative to stimulatory/positive ones), depending on the bacterial species analyzed, the nature of the emitted magnetic signals, and the time of magnetic exposure $[7,26,33]$. Moreover, although research related to the influence of MFs on microor- 
ganisms has been globally conducted for several decades, the mechanisms standing behind MF-induced bacterial stimulation/inhibition are not understood. Therefore, it is still not possible to predict, with absolute certainty, how a particular microorganism would behave when exposed to an MF of specific parameters.

As regards the dependence of effects on the physical parameters of MF, in particular its intensity or frequency and the duration of exposure, most of the relationships have been well described and explained. Nevertheless, apart from the physics point of view, the possible effects of magnetic exposure should also be considered from a biological perspective, and in the context of the present study, primarily from the microbiological point of view. In this case, a number of theories suggesting what the observed effect of exposure may depend on can be found in the relevant literature. As an example, according to several authors $[7,26,33]$, biological effects of MFs on the biological function of bacterial cells can be distinguished (inhibitory or stimulatory), depending on the nature of emitted signals and the time of exposure, the microorganism species $[18,20,21]$, the structure and composition of the cell wall $[24,25]$, the bacterial cell shape $[7,10,34]$, or both the shape of the bacterial cell and the structure of the cell wall [25]. However, a thorough review of the available literature shows a lack of consistency of the results obtained concerning the above cellular parameters. Therefore, even when the same type of MF is applied, the results indicating positive and negative effects of exposure for the same species of microorganism are reported (Table 2 ).

Admittedly, different researchers use different MF-generating systems and conduct their research using different MF parameters, which certainly decreases the possibility of a direct comparison of the obtained results. It should also be noted that, so far, there have been only a few research projects presenting the impact of MF on different bacterial strains belonging to the same species. However, even if such studies were performed, the strains' answer to the exposure was not analyzed individually, or the number of scrutinized strains was too low to draw any significant conclusions regarding their different sensitivities to the magnetic exposure $[9,22]$.

Therefore, in the present work, we attempted to take a step towards systematization of the knowledge in this area, focusing on the impact of only one type of MF (i.e., rotating magnetic field (RMF)) on several species of different bacteria, each represented by several strains. The agenda behind this approach was to investigate how a particular type of MF affects various strains belonging to the same bacterial species.

The purpose of the present study was to assess the effect of the RMF (of two distinguished frequencies, 5 and $50 \mathrm{~Hz}$ ) on the growth and cell viability/cellular metabolic activity (frequently studied cell parameters of bacteria exposed to MFs) of different bacterial strains (including wild and reference strains) belonging to eight species: Staphylococcus aureus, Pseudomonas aeruginosa, Proteus mirabilis, Klebsiella pneumoniae, Enterococcus faecalis, Enterobacter cloacae, Moraxella catarrhalis, and Bacillus cereus. Moreover, an additional group of $S$. aureus belonging to a single clone (clonal type) was also included in the experiment. The selected bacterial species differed from each other in terms of cell shape (rods/cocci), cell wall structure (Gram-negative and Gram-positive), metabolism (aerobic/facultatively anaerobic), motility, and ability to form spores. We hypothesized that the effect of the RMF is not related (or at least not always) to the above characteristics of a given microorganism but depends on the specifics of an individual strain, and therefore, the determination of the impact of MFs on microorganisms should be performed much more precisely than it has been performed to date. 
Table 2. The effects exerted by different types of magnetic fields on bacteria.

\begin{tabular}{|c|c|c|c|}
\hline $\begin{array}{l}\text { Bacterial } \\
\text { Species }\end{array}$ & Positive Effect (Stimulating Effect) & Negative Effect (Inhibitory Effect) & No Influence \\
\hline \multicolumn{4}{|c|}{ Gram-positive cocci } \\
\hline E. faecalis & Konopacki and Rakoczy, 2019 [24] RMF & Inhan-Garip et al., 2011 [13] ELF-EMF & \\
\hline S. aureus & $\begin{array}{c}\text { Fijałkowski et al., } 2013 \text { [17] }]^{\text {RMF }} \\
\text { Nawrotek et al., } 2014 \text { [18] }{ }^{\text {RMF }} \\
\text { Fijałkowski et al., } 2015 \text { [20] } \text { [MF }^{\text {RMF }} \\
\text { Tessaro et al., 2015 [21] }{ }^{\text {ELF-EMF }} \\
\text { Konopacki and Rakoczy, } 2019 \text { [24] }{ }^{\text {RMF }}\end{array}$ & $\begin{array}{c}\text { Kohno et al., } 2000 \text { [6] SMF } \\
\text { Fojt et al., 2004 [7] } \text { LF-EMF }^{\text {LF }} \\
\text { Kermanshahi et al., 2005 [9] SEF } \\
\text { Strašák et al., } 2005 \text { [10] MF } \\
\text { Inhan-Garip et al., } 2011 \text { [13] } \\
\text { Bayir et al., 2015 [19] ELF-EMF } \\
\text { Masood et al., 2020 [25] } \\
\text { Obeimeier et al., } 2009 \text { [11] }{ }^{\text {LF-EMF }}\end{array}$ & $\begin{array}{l}\text { Grosman et al., } 1992 \text { [5] SMF } \\
\text { Lászlo and Kutasi, } 2010 \text { [12] } \\
\text { SMF } \\
\text { Salmen et al., } 2018 \text { [23] HF-EMF }\end{array}$ \\
\hline S. epidermidis & Tessaro et al., 2015 [21] ELF-EMF & $\begin{array}{l}\text { Inhan-Garip et al., } 2011 \text { [13] }{ }^{\text {ELF-EMF }} \\
\text { Masood et al., } 2020 \text { [25] SMF/O-MF } \\
\text { Bajpai et al., } 2012 \text { [14] }{ }^{\text {MI-SMF }}\end{array}$ & Salmen et al., 2018 [23] HF-EMF \\
\hline S. mutans & $\begin{array}{c}\text { Fijałkowski et al., } 2015 \text { [20] }{ }^{\mathrm{RMF}} \\
\text { Konopacki and Rakoczy, } 2019 \text { [24] }{ }^{\mathrm{RMF}}\end{array}$ & Kohno et al., 2000 [6] SMF & \\
\hline S. xylosus & Fijałkowski et al., 2015 [20] RMF & & \\
\hline \multicolumn{4}{|c|}{ Gram-negative cocci } \\
\hline P. denitrificans & & Strašák et al., 2005 [10] ${ }^{\mathrm{MF}}$ & \\
\hline \multicolumn{4}{|c|}{ Gram-positive rod } \\
\hline B. circulans & & & Lászlo and Kutasi, 2010 [12] SMF \\
\hline \multicolumn{4}{|c|}{ Gram-negative rod } \\
\hline A. baumannii & & Fijałkowski et al., 2015 [20] ${ }^{\mathrm{RMF}}$ & \\
\hline E. coli & $\begin{array}{l}\text { Fijałkowski et al., } 2013 \text { [17] }{ }^{\text {RMF }} \\
\text { Fijałkowski et al., } 2015[20]^{\text {RMF }} \\
\text { Nawrotek et al., } 2014 \text { [18] }{ }^{\text {RMF }}\end{array}$ & 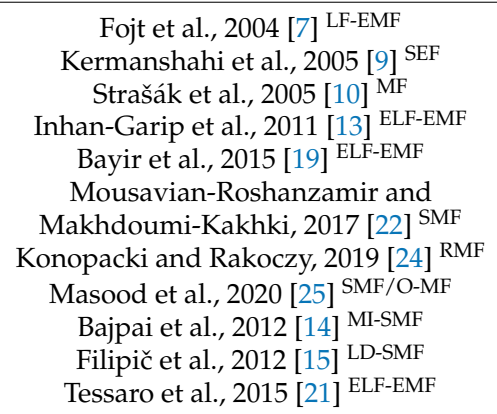 & $\begin{array}{l}\text { Grosman et al., } 1992 \text { [5] }^{\text {SMF }} \\
\text { Kohno et al., } 2000 \text { [6] }{ }^{\text {SMF }} \\
\text { Lászlo and Kutasi, } 2010 \text { [12] } \\
\text { SegF } \\
\text { Segatore et al., 2012 [16] }{ }^{\text {ELF-EMF }}\end{array}$ \\
\hline K. oxytoca & Fijałkowski et al., 2015 [20] RMF & Konopacki and Rakoczy, 2019 [24] RMF & \\
\hline K. pneumoniae & & Inhan-Garip et al., 2011 [13] ${ }^{\text {ELF-EMF }}$ & \\
\hline P. aeruginosa & & $\begin{array}{l}\text { Inhan-Garip et al., } 2011 \text { [13] }{ }^{\text {ELF-EMF }} \\
\text { Fijałkowski et al., } 2015 \text { [20] RMF } \\
\text { Salmen et al., } 2018 \text { [23] }]^{\text {HF-EMF }} \\
\text { Masood et al., } 2020 \text { [25] SMF/O-MG }\end{array}$ & Segatore et al., 2012 [16] ELF-EMF \\
\hline P. fluorescens & & & Lászlo and Kutasi, 2010 [12] SMF \\
\hline P. putida & & Filipič et al., 2012 [15] LD-SMF & \\
\hline S. enteritidis & & & Lászlo and Kutasi, 2010 [12] SMF \\
\hline S. marcescens & Fijałkowski et al., 2015 [20] RMF & Tessaro et al., 2015 [21] ELF-EMF & $\begin{array}{c}\text { Lászlo and Kutasi, } 2010 \text { [12] SMF } \\
\text { Konopacki and Rakoczy, } 2019 \text { [24] }{ }^{\text {RMF }}\end{array}$ \\
\hline
\end{tabular}

\section{Results}

\subsection{Analysis of the Molecular Diversity between Strains of S. aureus}

Macrorestrictive DNA analysis of the investigated staphylococci using PFGE showed that all isolates belonged to different PFGE types and, according to the established criteria (genetic similarity coefficient (Sab) was 65.7\%), constituted different clones (Figure 1). Each 
S. aureus strain revealed also a distinctive, individual phenotypic pattern and, therefore, according to the established criteria (distinctive features of the strains considered for establishing a biotype), constituted a different biotype (Table 3 and Supplementary Table S1).
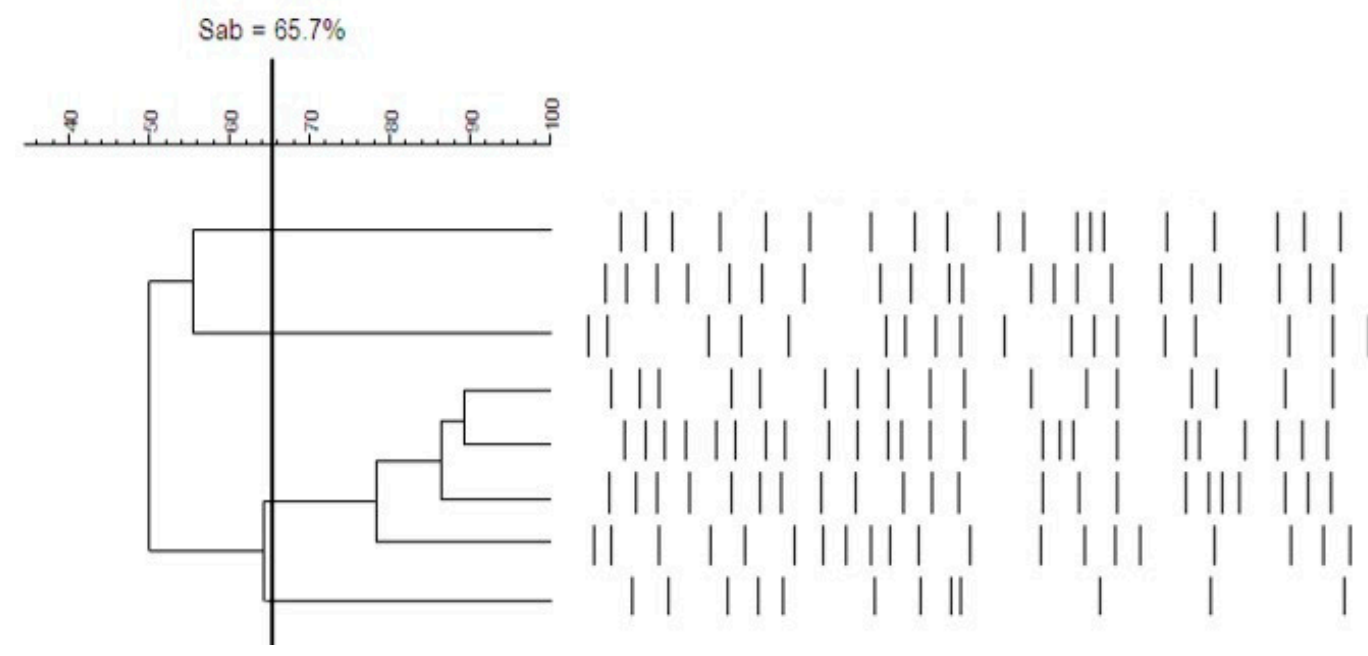

\section{Strain}

\begin{tabular}{ll}
\hline S.aureus 1 & A3 \\
S.aureus 2 & U1 \\
S.aureus 3 & U2 \\
S.aureus 4 & B1 \\
S.aureus 5 & B2 \\
S.aureus 6 & B3 \\
S.aureus 7 & B4 \\
ATCC 6538 & C1
\end{tabular}

Figure 1. Dendrogram of PFGE clusters and genotypic relationships of S. aureus isolates. Cut-off point is equal to $65.7(\mathrm{Sab}=65.7 \%)$.

Table 3. Phenotypic patterns of S. aureus strains.

\begin{tabular}{ccccccccc}
\hline $\begin{array}{c}\text { Phenotypic } \\
\text { Pattern }\end{array}$ & $\mathbf{1}$ & $\mathbf{2}$ & $\mathbf{3}$ & $\mathbf{4}$ & $\mathbf{5}$ & $\mathbf{6}$ & $\mathbf{7}$ & $\begin{array}{c}\text { ATCC } \\
\mathbf{6 5 3 8}\end{array}$ \\
\hline dRIB & - & - & - & - & - & - & + & - \\
NOVO & - & + & - & - & - & - & + & - \\
ILATk & + & - & + & - & - & + & + & + \\
O129R & + & + & + & + & + & + & + & - \\
LAC & - & - & + & - & - & - & - & - \\
NAG & + & + & + & - & + & + & + & + \\
BGAL & + & - & + & - & + & - & - & - \\
AMAN & - & + & - & - & - & - & - & - \\
MBdG & + & - & - & + & + & + & + & - \\
AGLU & + & + & - & + & + & + & + & - \\
dGAL & + & + & + & - & + & - & - & + \\
ADH2s & + & - & - & - & - & - & - & + \\
\hline
\end{tabular}

dRIB-D-ribose, NOVO-novobiocin resistance, ILATk-L-lactate alkalinization, O129R-O/129 resistance (comp.vibrio.), LAC-lactose, NAG- $N$-acetyl-D-glucosamine, BGAL- $\beta$-galactosidase, AMAN- $\alpha$ mannosidase, MBdG-methyl-B-D-glucopyranoside, AGLU— $\alpha$-glucosidase, dGAL-D-galactose, ADH2sarginine dihydrolase 2 . The most differentiating features are summarized in the above table; the complete biochemical characteristics are summarized in Supplementary Table S1.

\subsection{The Study of Growth Dynamics and Cellular Metabolic Activity}

Because in the preliminary study we confirmed that the results obtained in AlamarBlue were determined to a greater extent by the changes in cellular metabolic activity than cell viability, we assumed that the results obtained in this assay would be presented as changes in cellular metabolic activity (Figure 2). 
(a)

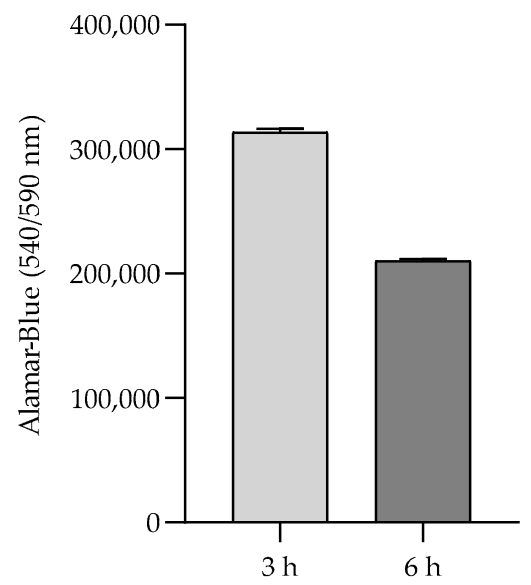

(b)

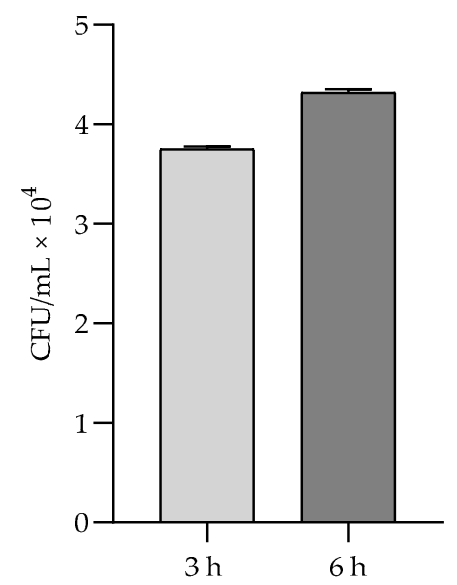

(c)

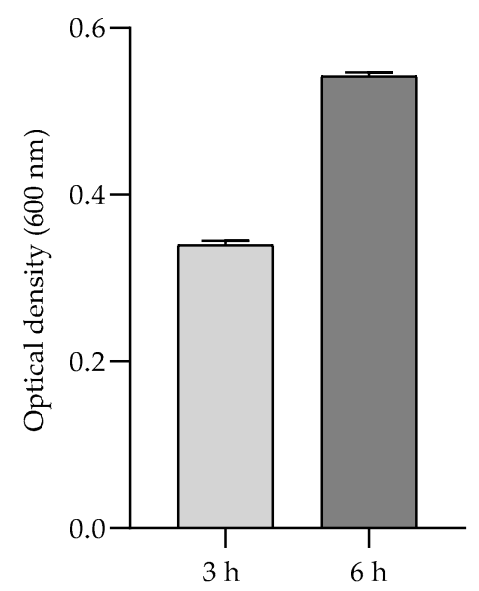

Figure 2. Representative results obtained in different tests: (a) Alamar-Blue (cellular metabolic activity/viability), (b) CFU number (viability), and (c) optical density (growth rate) for the MRSA no. 3 strain exposed to an RMF of $50 \mathrm{~Hz}$. Alamar-Blue shows the changes in cellular metabolic activity and viability (viable cells = metabolically active cells); CFU number shows changes in the number of viable cells (able to form colonies); and optical density shows the growth rate of bacteria, although it does not distinguish between live and dead cells.

Staphylococcus aureus. The results of the effect of the RMF on the growth dynamics and metabolic activity of S. aureus cells are presented in Figure 3a (the results of individual statistical analyses are shown in Supplementary Material). In general, the results showed a varied influence of the RMF on the growth dynamics and cellular metabolic activity of $S$. aureus, diversified to the greatest extent depending on the bacterial isolate/strain that was exposed to the RMF, as well as depending on the exposure time, and to a lesser extent depending on the frequency of the generated magnetic field ( $5 \mathrm{vs} .50 \mathrm{~Hz})$. The reference strain (ATCC 6538) was characterized by a continuous decrease in growth rate. Moreover, the results obtained after 6 and $9 \mathrm{~h}$ of exposure to a RMF of $5 \mathrm{~Hz}$ and after $9 \mathrm{~h}$ of exposure to an RMF of $50 \mathrm{~Hz}$ were statistically significantly lower than the values obtained for the control cultures not exposed to an RMF. A progressive decrease in the growth rate, although not as substantial as in the case of the reference strain, was also noted in the cultures of wild strain nos. 4 and 5, and this trend was clearly more pronounced when an RMF with a frequency of $5 \mathrm{~Hz}$ was applied. The growth rate of isolate no. 1, after 3 and $6 \mathrm{~h}$ of exposure to the RMF, regardless of its frequency, was not statistically significantly different as compared with the control, although during exposure to an RMF of $50 \mathrm{~Hz}$, the frequency of the growth rate markedly increased. Nevertheless, after $9 \mathrm{~h}$ of exposure to the RMF (both frequencies) of cultures with this staphylococcal strain, a significant decrease in the growth rate was found. Strain no. 2, in turn, was characterized by a continuous increase in growth rate when exposed to an RMF of 5 and $50 \mathrm{~Hz}$, and strain nos. 3 and 7 did not show any significant changes in this parameter as a result of the magnetic exposure, regardless of its frequency or duration. Therefore, it can be summarized that most of the growth profiles differed so that if only one strain was selected for the purposes of the study, the final conclusion from the obtained results could be different-depending on which strain was included in the analysis.

Similar to the results of growth dynamics, also the results presenting changes in the cellular metabolic activity, which is the second parameter analyzed in the current study, varied between individual strains. In the cultures of the reference strain (ATCC 6538) exposed to an RMF of $5 \mathrm{~Hz}$, no significant changes were found, while a significant increase in cellular metabolic activity was observed after $3 \mathrm{~h}$ of exposure to an RMF of $50 \mathrm{~Hz}$. In the case of strain nos. 1 and 4 , a continuous decrease in cellular metabolic activity was 
observed. For strain no. 1, significant differences as compared with the unexposed control were found after $9 \mathrm{~h}$ of exposure to an RMF of $5 \mathrm{~Hz}$ (decrease in cellular metabolic activity as compared with the control) and after $3 \mathrm{~h}$ of exposure to an RMF of $50 \mathrm{~Hz}$ (the results were higher than in the control), whereas in the case of isolate no. 4, significant differences were obtained after 3 and $9 \mathrm{~h}$ of exposure regardless of the RMF frequencies (the values were higher and lower as compared with the control, respectively). The cellular metabolic activity of strain nos. 2 and 3 remained below the values obtained for the unexposed controls, except for strain no. 3, whose cellular metabolic activity after $9 \mathrm{~h}$ of exposure to an RMF of $50 \mathrm{~Hz}$ increased above the values recorded for the control. Nevertheless, the only significant difference (value significantly lower than for the unexposed control) was found for isolate no. 3 after $3 \mathrm{~h}$ of exposure to an RMF of $5 \mathrm{~Hz}$. In turn, in the case of strain no. 5 , there was a significant increase in cellular metabolic activity as compared with the unexposed control in all time points of measurements, but only during exposure to an RMF of $5 \mathrm{~Hz}$. Whereas when the culture of this strain was exposed to an RMF of $50 \mathrm{~Hz}$, the same tendency was observed except for the last time point, where the value of cellular metabolic activity was slightly lower than for the unexposed control. In the cultures of strain nos. 6 and 7, cellular metabolic activity was above the values obtained for the control, regardless the time point of measurements and the RMF frequencies, while in the case of strain no. 7 and exposure to an RMF of $5 \mathrm{~Hz}$, the highest values of cellular metabolic activity were obtained after $9 \mathrm{~h}$ of the experiment, and when the frequency of the RMF was $50 \mathrm{~Hz}$, after $3 \mathrm{~h}$.

For the group of staphylococci belonging to one clonal type, the results were not as noticeably differentiated as for the group of $S$. aureus representing different clones (Figure 3b). Nevertheless, also in this group, different trends in the changes of the analyzed cellular parameters under the influence of the RMF were found. As in the case of the above-discussed group of genetically diverse staphylococci, also in this group, the RMF characteristics were the least significant determinant of the differentiation of the results. When analyzing the results obtained after $3 \mathrm{~h}$ of exposure to the RMF, it can be noticed that strain no. 1 was the only one that was characterized by a lower growth rate as compared with the unexposed control (however, the difference was not statistically significant). In contrast, strain no. 2 was the only one that was characterized by a statistically significantly higher growth rate as compared with the unexposed control. After $6 \mathrm{~h}$ of RMF exposure, the only significant difference (an increase) in growth rate in comparison with the control was recorded for strain no. 3 exposed to an RMF of $5 \mathrm{~Hz}$, whereas no significant differences in comparison with the control were found for cultures exposed to the RMF for $9 \mathrm{~h}$.

Although they did not show a recurring trend of changes, the results of cellular metabolic activity were clearly less differentiated as compared with the results of growth dynamics. Apart from strain no. 3, exposed to an RMF of $5 \mathrm{~Hz}$, in all other cultures, the lowest values of cellular metabolic activity were obtained after $6 \mathrm{~h}$ of exposure, and additionally for strain no. 3, equally low values were also obtained after $3 \mathrm{~h}$ of exposure. After $9 \mathrm{~h}$ of exposure to an RMF of $5 \mathrm{~Hz}$, a significant increase in cellular metabolic activity was found for all strains except for strain no. 4. In contrast, this strain (no. 4) was the only one whose metabolic activity increased due to exposure to an RMF of $50 \mathrm{~Hz}$ (after 9 h). 


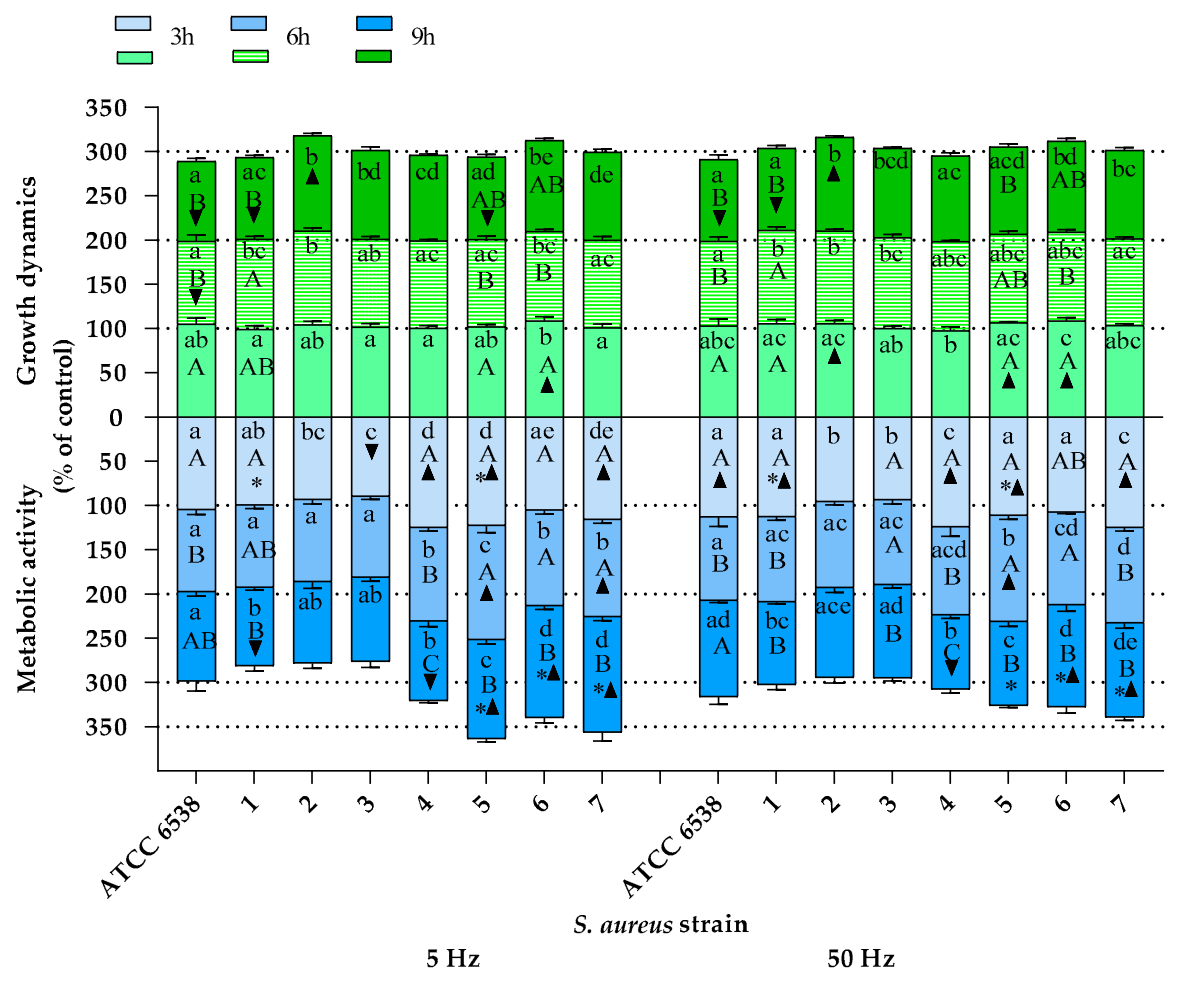

(b)

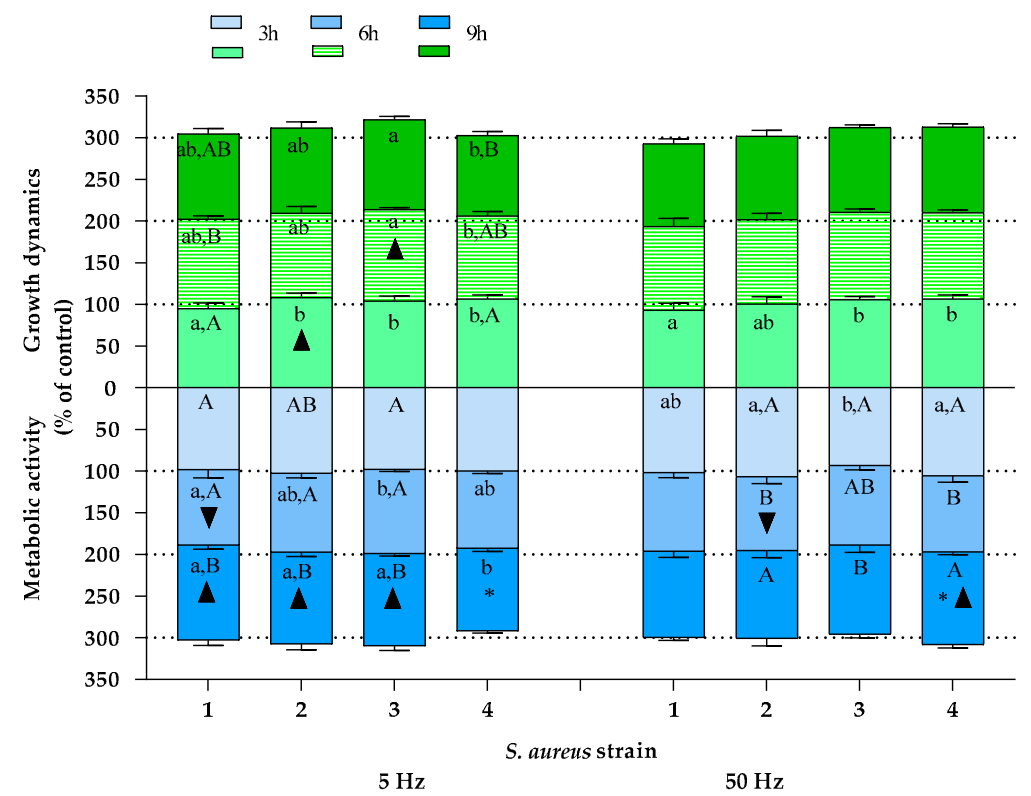

Figure 3. Growth dynamics and cellular metabolic activity of $S$. aureus cultures exposed to a rotating magnetic field ( 5 and $50 \mathrm{~Hz}$ ). (a) S. aureus strains representing different clonal types. (b) S. aureus strains representing one clonal type. Data are expressed as \% of control. The results are presented as a mean \pm SEM calculated using six values (three from each biological replicate). Lowercase letters indicate significant differences between strains at a specific time; capital letters indicate significant differences between time points of measurements for a particular strain; the asterisk symbol $\left(^{*}\right)$ indicates significant differences between RMF frequencies ( $5 \mathrm{vs.} 50 \mathrm{~Hz}$ ); $\mathbf{\Delta} \mathbf{\nabla}$-significant differences compared with the unexposed control, taking into account the trend (stimulation and inhibition, respectively) $(p<0.005)$. 
Other species of bacteria. As shown in Figure 4, also in the case of the remaining bacterial species included in the analyses, the results indicating both changes in growth rate and in cellular metabolic activity due to RMF exposure showed a significant differentiation depending on the bacterial strain analyzed. Similarly, as was found for S. aureus strains, the effect of the RMF was mainly determined by the duration of RMF exposure, with the observed trend being in most cases different for various strains of the same species. However, a certain kind of a reproducible trend between strains was found for $P$. aeruginosa strains in the $3 \mathrm{rd} h$ of the experiment, where the results of growth rate, except for the reference strain (ATCC 15442) exposed to an RMF of $50 \mathrm{~Hz}$, were not statistically significantly different as compared with the control (Figure 4a). Furthermore, also except for the reference strain, but exposed to an RMF of $5 \mathrm{~Hz}$, the growth rate of other strains decreased (all the values were also significantly lower as compared with the unexposed control) after $6 \mathrm{~h}$ of RMF exposure regardless of RMF frequency. Only the results obtained for the reference strain after $9 \mathrm{~h}$ of exposure to an RMF of $5 \mathrm{~Hz}$ and after 3 and $9 \mathrm{~h}$ of exposure to an RMF of $50 \mathrm{~Hz}$ were higher as compared with the unexposed controls. On the other hand, in the remaining strains, the growth rate measured after $9 \mathrm{~h}$ of magnetic exposure was always below the values obtained for the controls (although the results were not always statistically significant). A repeatable trend was also observed in the analysis of cellular metabolic activity-all the values of this parameter obtained after $3 \mathrm{~h}$ and, except for strain no. 1, also after $6 \mathrm{~h}$ of exposure (both RMF frequencies) were higher as compared with the control. In contrast, no repeatable trend was observed after $9 \mathrm{~h}$ of RMF exposure.

In contrast to the results obtained for P. aeruginosa, there were no recurring trends in the changes of growth dynamics in cultures of E. faecalis, although in most cases, the results obtained in RMF-exposed cultures were not statistically different as compared with the unexposed controls (Figure $4 \mathrm{~b}$ ). The only exception was found for strain no. 2-the cultures of this strain after $3 \mathrm{~h}$ of exposure to an RMF of $5 \mathrm{~Hz}$ were characterized by a statistically significantly higher growth rate as compared with the unexposed controls. Moreover, the same trend was also found for this strain when it was exposed for 3 and $6 \mathrm{~h}$ to an RMF of $50 \mathrm{~Hz}$. Similarly, also in the case of cellular metabolic activity, strain no. 2 was the most distinct in terms of the observed changes in this parameter as a result of RMF exposure compared with the other strains of Enterococcus. In turn, three distinct profiles of changes in growth dynamics under the influence of the RMF were observed in E. cloacae cultures (Figure 4c). The first of them was "none" (absence of significant effects) or only slight effect of the RMF on the changes in growth rate, the second one can be described as an increased growth rate after $6 \mathrm{~h}$, and the third one showed a decreased growth rate after 3 and 9 h of RMF exposure. All E. cloacae strains showed the highest cellular metabolic activity after $3 \mathrm{~h}$ of RMF exposure. In the case of strain nos. 1 and 2, a continuous decrease in this parameter was observed (below the values obtained for the unexposed control after $9 \mathrm{~h}$ of exposure). In the case of $P$. mirabilis, no recurring trend in the observed changes was noticed, in the case of both growth dynamics and cellular metabolic activity (Figure $4 \mathrm{~d}$ ). However, it can be seen that most of the statistically significant differences between the RMF-exposed and unexposed cultures indicated a reduced growth rate and, at the same time, increased cellular metabolic activity under the influence of the RMF. The growth rate of K. pneumoniae, regardless of the strain, at the first time point of measurement was slightly lower than the one obtained for the control (Figure 4e). In contrast, after $6 \mathrm{~h}$ of RMF exposure, the upward trend dominated, and finally, after $9 \mathrm{~h}$, there was no statistically significant difference between RMF-exposed and unexposed cultures. The analysis of $B$. cereus allowed for selecting three different profiles of changes in the growth rate due to RMF exposure, one of which (gradual decrease) was repeated in cultures of two strains (PCM 449 and strain no. 1) (Figure 4f). In the analyses of cellular metabolic activity, it was found that three strains were characterized by the highest values of this parameter after $3 \mathrm{~h}$, followed by its decrease after $6 \mathrm{~h}$ of exposure to the RMF (PCM 497 and strain nos. 1 and 3). After $9 \mathrm{~h}$ of exposure to the RMF, except for strain no. 1 exposed to an RMF of $5 \mathrm{~Hz}$, the growth rate values for the remaining strains, regardless of RMF frequency, did not differ 
from the unexposed control. In the cultures of $M$. catarrhalis, all strains showed the highest growth rate after $6 \mathrm{~h}$ of magnetic exposure, although the results differed between strains (e.g., only strain no. 1, when exposed to the RMF, proliferated more rapidly in comparison with the unexposed control (Figure $4 \mathrm{~g}$ )). Furthermore, all values of this parameter obtained after 3 and $9 \mathrm{~h}$ of exposure were lower than in the control (except for strain no. 2 exposed to an RMF of $5 \mathrm{~Hz}$ for $3 \mathrm{~h}$ and the strains PCM 2340 and no. 1 exposed to an RMF of $5 \mathrm{~Hz}$ for $9 \mathrm{~h}$, the rest of the results were statistically significantly different in comparison with the control). In turn, in the case of cellular metabolic activity, the trends of changes in this parameter were not repeated between the analyzed strains.

(a)

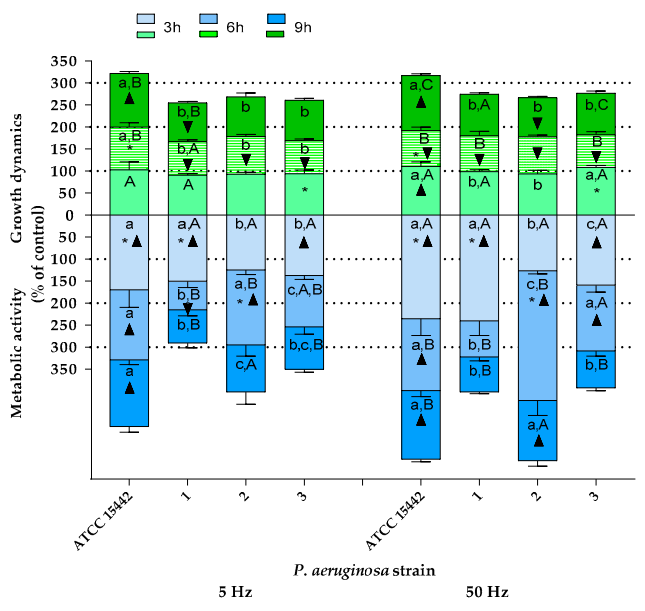

(c)

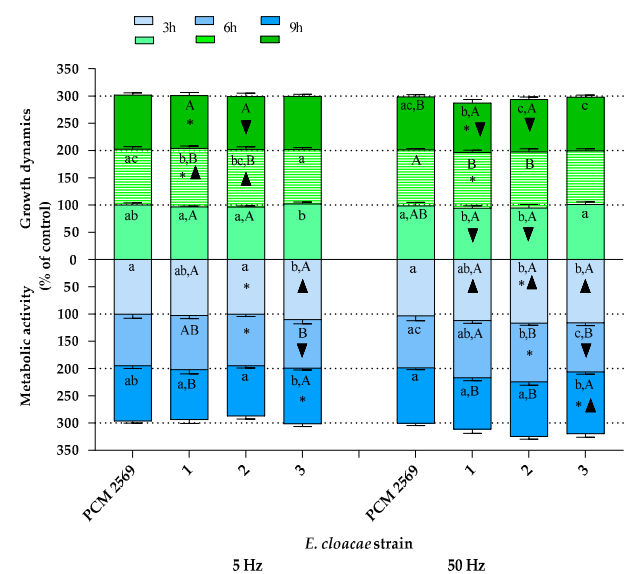

(b)

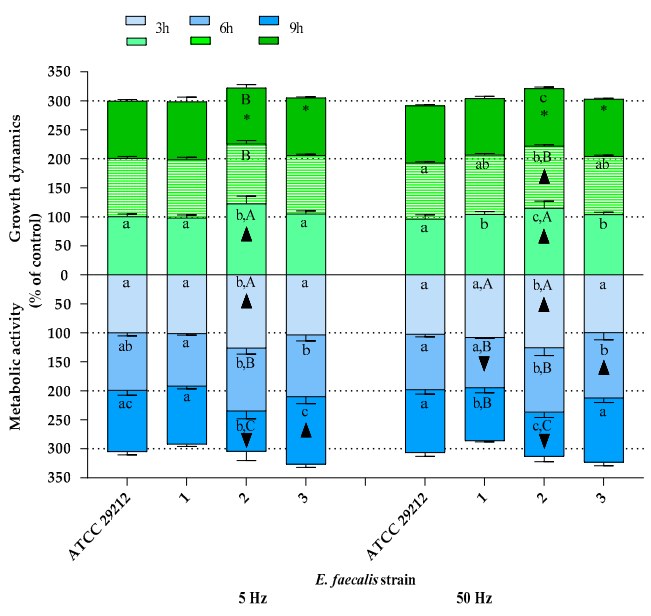

(d)

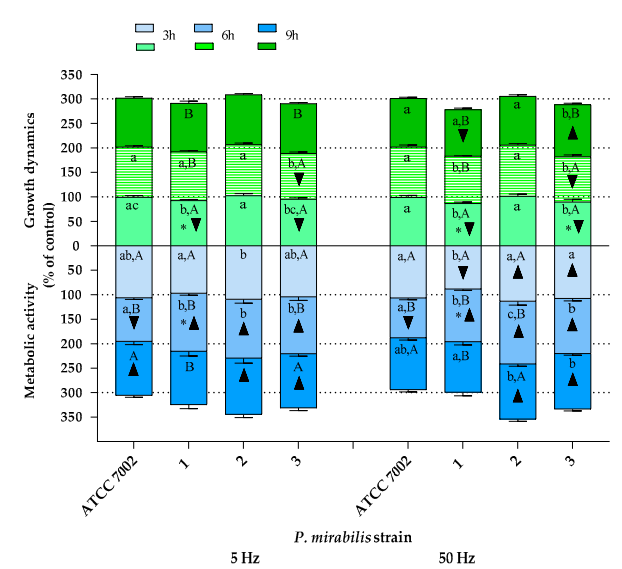

Figure 4. Cont. 
(e)

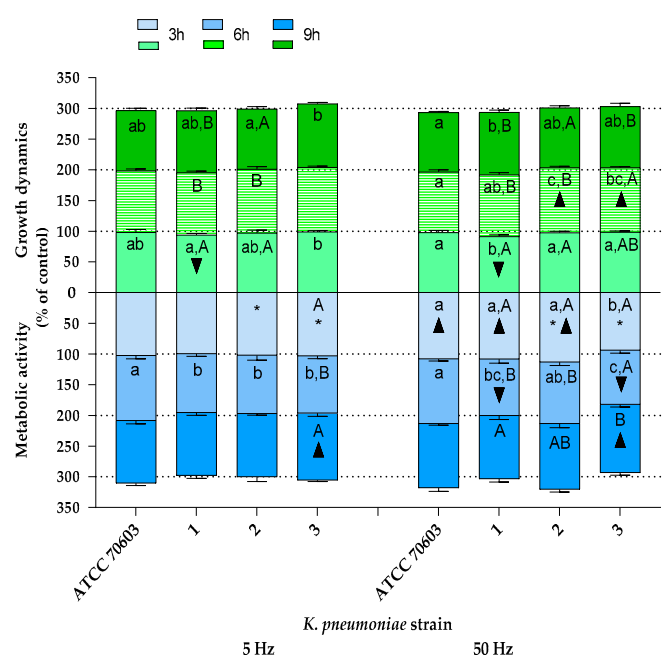

(f)

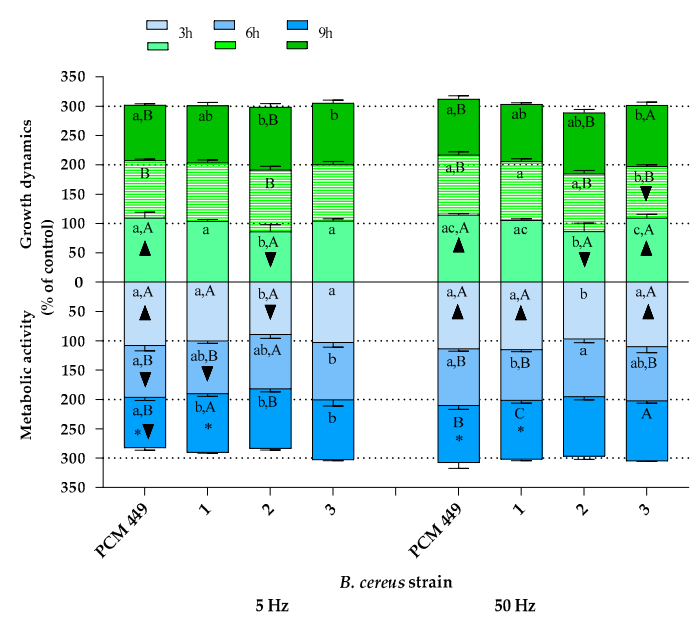

(g)

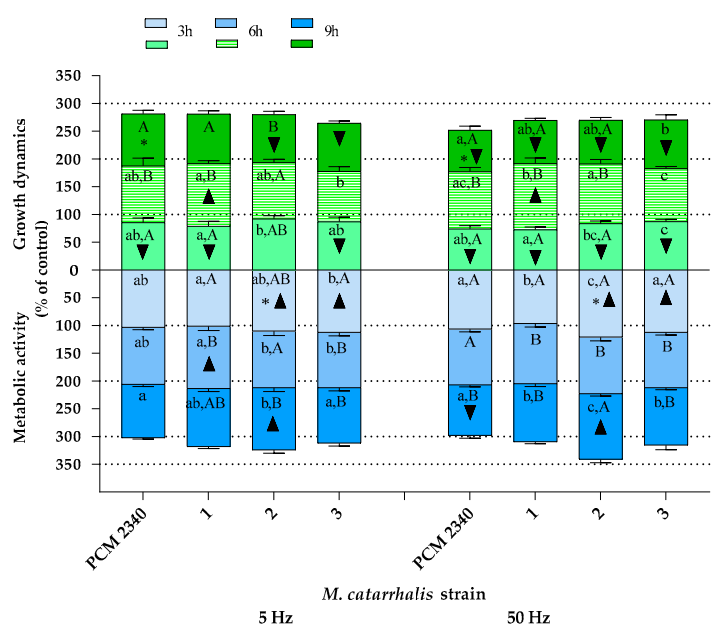

Figure 4. Growth dynamics and cellular metabolic activity of different bacterial strains and species exposed to a rotating magnetic field (5 and $50 \mathrm{~Hz}$ ): (a) P. aeruginosa, (b) E. faecalis, (c) E. cloacae, (d) P. mirabilis, (e) K. pneumoniae, (f) B. cereus, (g) M. catarrhalis. Data are expressed as \% of the control. The results are presented as a mean \pm SEM calculated using six values (three from each biological replicate). Lowercase letters indicate significant differences between strains at a specific time; capital letters indicate significant differences between time points of measurements for a particular strain; the asterisk symbol $(*)$ indicates significant differences between the RMF frequencies ( $5 \mathrm{v} .50 \mathrm{~Hz}$ ); $\boldsymbol{\Delta} \mathbf{\nabla}$-significant differences compared with the unexposed control, taking into account the trend (stimulation and inhibition, respectively) $(p<0.005)$.

\section{Discussion}

Our research has proven that, apart from the previously described factors related primarily to the characteristics of the $\mathrm{MF}$, one of the key parameters affecting the final result of MF influence is the specificity of a given microorganism. By the specificity of a microorganism, we mean not only the species, cell shape, or cell wall structure, as widely considered in the literature $[7,10,24,25]$, but also the individual set of features characteristic for a given strain of a microorganism within a species, referred to as the intraspecies variability [35]. We showed that, depending on a given strain, the effect exerted by the RMF (the particular type of MF used for the purposes of the current analysis) was positive (i.e., manifested itself as the increase in growth rate or/and cellular metabolic activity), or it was negative (i.e., manifested itself as a reduction of both aforementioned features). In turn, for some strains exposed to the RMF, we also observed no biological effect. Thus, it can be stated, perverse as that sounds, that the results obtained in the current study are 
consistent with all data previously reported by other authors, even though they are often contradictory (Tables 1 and 2).

As already mentioned, so far, the research within the scope of analysis performed in the current study has been carried out with the use of different species or different groups (due to the selected characteristics) of microorganisms, but not with the use of different strains belonging to one species. Thus, the present study proved that by selecting the appropriate strain of the microorganisms, we can draw completely different conclusions concerning the influence of the MF (or RMF, at least) on them. Interestingly, even when we used one clonal type of $S$. aureus represented by several strains belonging to different biotypes, the results of RMF exposure also varied (although the degree of differentiation was lower than for strains representing different clones). This observation additionally emphasizes the sensitivity of individual microorganisms to the activity of MFs. Of course, we are aware that in the present study, we used only one type of MF, but there are no reasons to believe that the results of such experiments would be different if another MF type was applied.

It should be noted that from the microbiological perspective, bacteria show a significant diversity, not only within the species, but even within the strain, and to some extent even within the clone. The general concept of species held by most bacteriologists could be formulated as follows: a species consists of strains of common origin that are more similar to each other than they are to any other strain [36]. The strain can be defined as an isolate or group of isolates of the same species by phenotypic characteristics or genotypic characteristics or both [37]. It should also be noted that bacterial strains can change over time. They undergo mutations, may lose plasmids, and acquire genetic material from other strains in the environment $[36,38]$. However, strains retain their identity even if their phenotype is changed. The term "clone" (genetically related isolates) is used to denote bacterial isolates that are indistinguishable from each other by a variety of genetic tests [36]. Thus, even strains and clones of one species are not identical in terms of such phenotypic features as, for example, biochemical, pathogenic, or antibiotic-resistant profile [39]. Therefore, taking into account that MFs affect the activity of enzymes involved in the metabolic processes of bacterial cells [40], as well as considering the differences in the phenotype (including the biochemical profile even between closely related strains of a given species), it seems that one should not expect that exposure to any kind of MF would have the same effect on each strain (despite these differences). The recommendations of EUCAST (European Committee on Antimicrobial Susceptibility Testing) [41] and CSLI (Clinical and Laboratory Standards Institute) [42] should be quoted as a significant example of the microbiological perspective. According to these recommendations, a separate examination of bacterial susceptibility to antibiotics should be carried out for each bacterial isolate/strain of a given species. These recommendations are obviously based on the undeniable observation that sensitivity to antimicrobial substances is unique for each strain isolated [43]. Similarly, the ability of bacteria to produce biofilm is well known to be strain dependent [44]. Therefore, it can be assumed that the observed effects of MFs on bacteria (apart from such physical parameters as type, distribution, magnetic induction, frequency, and duration of exposure), reflecting, for example antibiotic type, duration of exposure to the antibiotic, antibiotic concentration (in antibiotic susceptibility testing), or type and composition of the culture medium (in the case of biofilm analyses), cannot depend only on species affiliation or such variables as the structure and shape of bacterial cell, but also on the specific characteristics of each strain. In this context, one could compare here the claim that a specific type of MF stimulates Gram-positive bacteria, or even a specific representative of that group, such as S. aureus, and inhibits Gram-negative bacteria (e.g., P. aeruginosa) to a situation in which one would assume that an analogous division $(\mathrm{G}+/ \mathrm{G}-$ or $S$. aureus / P. aeruginosa) may be applied in determining bacterial resistance to a specific antibiotic (e.g., clindamycin). Obviously, microbiology knows the concept of natural antibiotic resistance covering whole groups of bacteria or only individual species, but the basis of this mechanism is of a different nature, 
which would be difficult to expect to manifest itself in the case of the effect observed after exposure to the MF.

The second important achievement resulting from our research was the confirmation that the effect of RMF exposure is additionally differentiated depending on exposure duration. Thus, by selecting the appropriate exposure time, it is also possible to observe a different nature of MF influence. The previous works of our research group $[18,20]$ and reports by other authors $[6,14,26]$ also indicated that the time of magnetic exposure is of key importance for the effect exerted on biological systems. The results of previous studies have shown that, depending on the MF exposure time, the observed effect may be positive (e.g., increased viability of bacteria) [30-32] or negative (e.g., reduced viability of bacteria) $[7,10,26]$. However, the results obtained in the current study revealed that the effect of the duration of magnetic exposure was additionally different depending on the strains, and in most analyses, no distinct trends were found between different strains of the same species. Therefore, depending on exposure duration, final conclusions from the obtained results may be different (i.e., the effect observed can be positive or negative, or there can be no effect). This observation is even more important if the results are analyzed through the prism of different strains within a given species.

The parameter that determined the effect of the RMF to a lesser extent (compared with the variability between strains and taking into account exposure time) was related to the RMF characteristics. In the current study, analyses included exposure to the RMF generated at two frequencies of the alternating current. In the case of the RMF setup used in the present study, the current frequency determined the intensity of the MF, but above all, it was responsible for the physical characteristics of the MF wave shape. As was shown by the simulative calculations, at $5 \mathrm{~Hz}$, the amplitude of the RMF was characterized by a longer period of magnetic induction $(B)$ maximal strength state that was $50 \mathrm{~ms}$ with $B \max 16.89 \mathrm{mT}$. In contrast, the RMF generated at $50 \mathrm{~Hz}$ (the highest current frequency that can be used in the setup) was characterized by a shorter period, with $5 \mathrm{~ms}$ time of magnetic induction maximal strength state with $B_{\max } 17.62 \mathrm{mT}$ (Figure 5; Supplementary Table S20). Simultaneously, the applied AC frequencies ( $5 \mathrm{~Hz}$ https: / / www.youtube.com/watch?v=aSkb6nAUgz8 and $50 \mathrm{~Hz}$ https: / / www.youtube.com/watch?v=ryiLdqfRnwM) generated magnetic flux rotation around the stator with different synchronous speeds of 150 and $1500 \mathrm{rpm}$, respectively (calculations performed on the basis of the manufacturer characteristics of the stators). Nevertheless, also in this case, we proved that by selecting the appropriate strain of a microorganism, it is possible to achieve results that will prove that the characteristics of the MF significantly influence the obtained results.

Our observations are essentially very basic, and in a sense, they can be seen as obvious. However, similar studies have not been performed before, and they should be treated as a foundation for a more cohesive approach, which should be undeniably developed if findings on the biological impact of MFs were to be introduced to biotechnology and medical microbiology on a large scale. The majority of previous research conducted by members of our scientific team and by other authors was carried out with the use of a single bacterial strain of a given species (Table 1). In the case of our research team, it took us at least several years to formulate the goals of the current study or, to put it simply, to notice the problem. Before that, like most other authors, we repeated the generally accepted research scheme in which various species of microorganisms, bacteria of different shapes, or of different cell wall structures were scrutinized, but the use of different strains within the same species was neglected. However, with time, not only we gained experience in the subject of the effects of MFs on microorganisms, but also we developed the research team, which currently consists of scientists from various scientific disciplines-clinical microbiologists, biotechnologists, engineers, electricians, and chemists. Currently, we have fully automated laboratories equipped with MF generators along with comprehensive control and measurement equipment. This allows us to conduct analyses with a very high degree of precision, characterized by high repeatability. Such a multidisciplinary approach allowed us to look at the analyzed challenge from a different, broader perspective 
and to get an insight into the importance of intraspecies variability. The observations described in the present article are related to the analyses that we are currently carrying out as a part of ongoing scientific projects. These studies concern the analysis of changes in the antibiotic sensitivity of microorganisms to various antibiotics under the influence of the RMF. In these studies, we used a large group of microorganisms of the same species (S. aureus and P. aeruginosa, mainly), including clinical and reference strains. Conducting the aforementioned analysis, we noticed that the effect of the RMF regarding the changes in antibiotic susceptibility cannot be defined as the same for different strains.

(a)

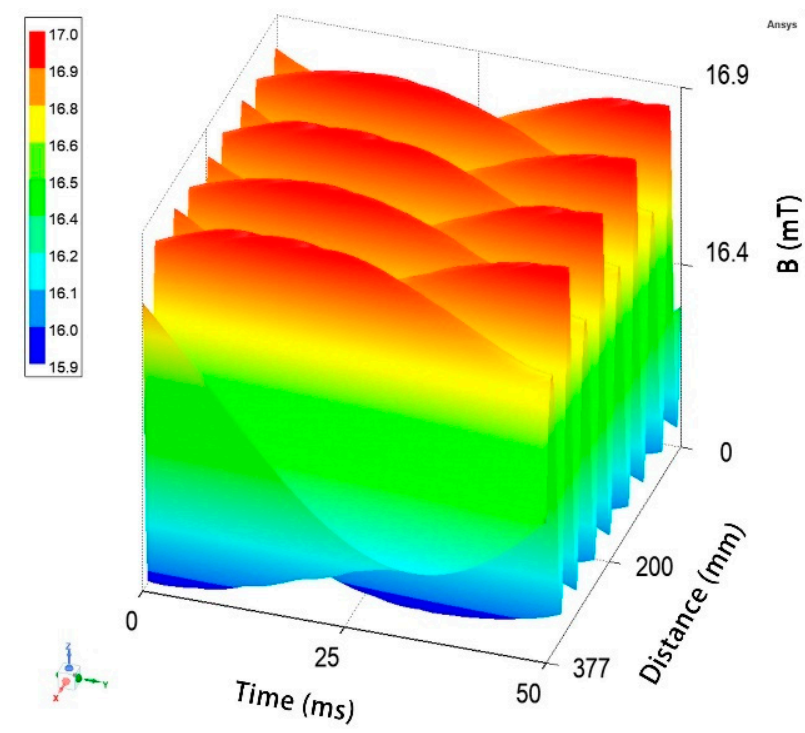

(c)

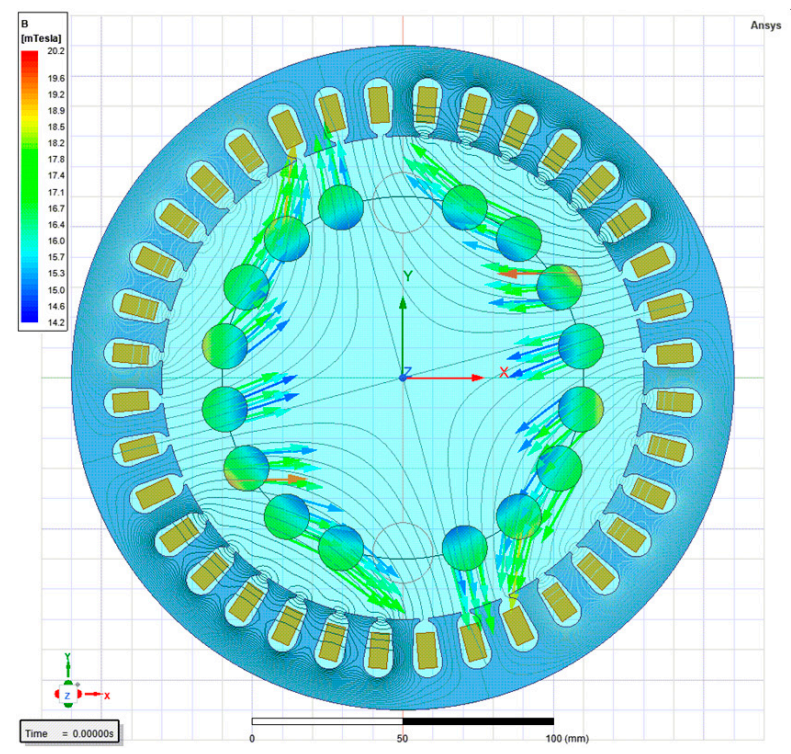

(b)

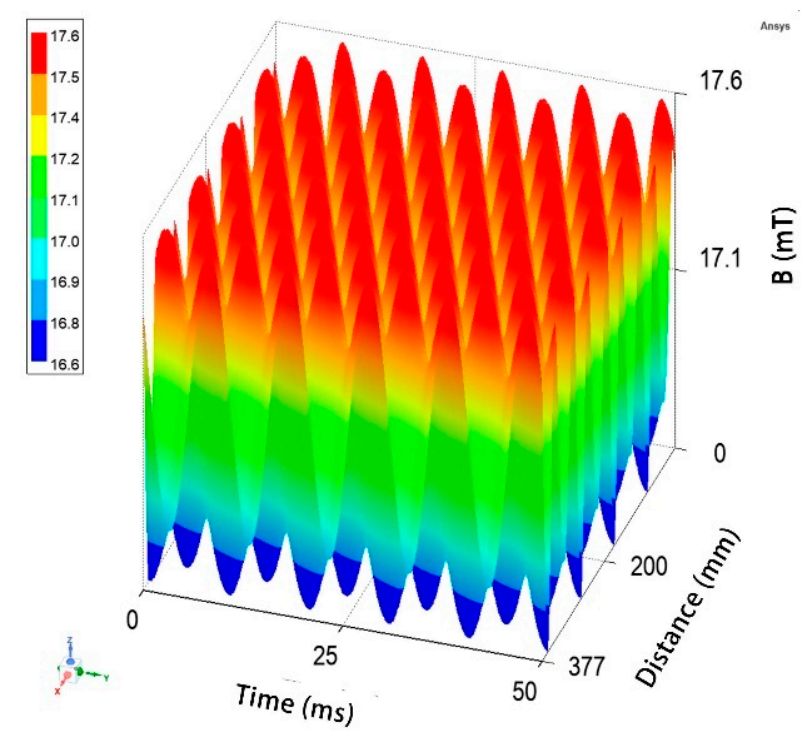

(d)

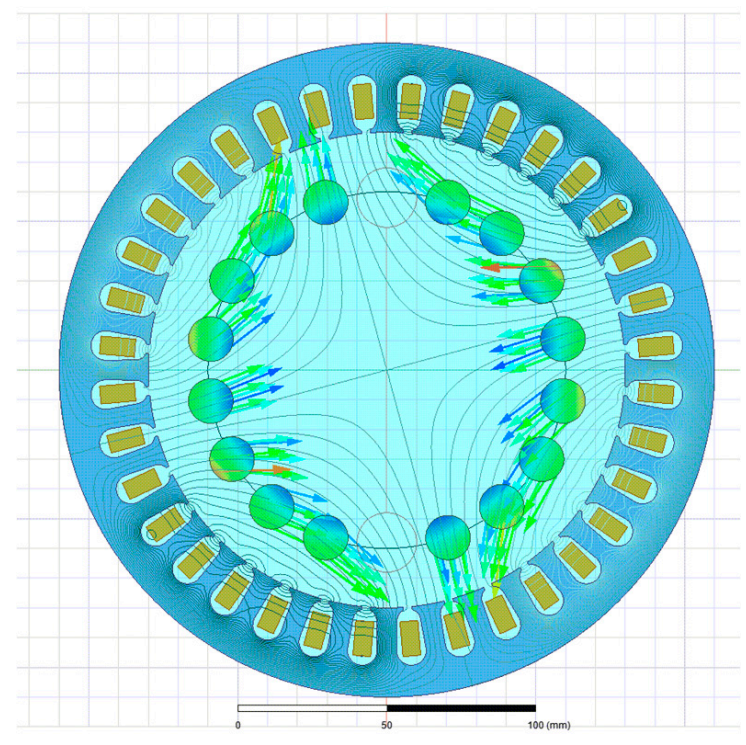

Figure 5. The changes of magnetic flux characteristic depending on the applied AC frequency: (a) $5 \mathrm{~Hz}$; (b) 50 $\mathrm{Hz}$ and visualization of periodical changes in magnetic flux density and the direction of magnetic flux density vectors inside the RMF reactor chamber at (c) $5 \mathrm{~Hz}$ https://www.youtube.com/watch?v=aSkb6nAUgz8and (d) $50 \mathrm{~Hz}$ https://www.youtube.com/watch?v=ryiLdqfRnwM. The circles in (c,d) show the arrangement of tubes with bacterial cultures.

Finally, we would like to point to the fact that the discoveries of recent years proved that, although bacteria are less complex organisms than eukaryotic yeasts or higher animals, 
they show a high level of intertwined interactions found in bacterial intra- and extraspecies communication [45-47], expression of virulence factors [48], or coordinated changes in the metabolic activity of community-forming cells [49]. In nature, strains of one species are subjected to a plethora of diverse stimuli, which modify the expression of their genes, resulting in multiple changes in bacterial phenotype and behavior [50]. Thus, bacterial strains of one species cannot be perceived as a number of identical biological automatons (which answer in exactly the same (binary) way to the same stimulus), but rather-similarly as in the case of animal or human communities-the type of answer to a stimulus is more of a Gaussian nature. It means that, if an adequately high population is used in the analysis, the obtained results will take the form of not only one main type of answer (manifested by the majority of strains) but also other types of answers (displayed by the minority of strains). As the issue of growing antimicrobial resistance to antibiotics shows, one should not underestimate these secondary types of reactions, because they may become dominant ones under specific circumstances. Therefore, as explicitly shown in the present study, the fact that intraspecies variability determines the effects exerted by the RMF (and the MF in general) should raise (among others) the question of the number of strains that should be analyzed (exposed to the specific type of MF) to draw proper conclusions and to obtain the desirable effect being the result of exposure. We would like to point out the fact that such a question is more and more frequently asked also in other types of microbiological studies, especially those concerning bacterial biofilm [51] and the use of antiseptics for chronic wound treatment $[52,53]$. With increasing knowledge concerning complex bacterial genetics, metabolomics, and proteomics, we have become aware that a study performed solely on the reference microorganism provides an answer concerning only this reference microorganism, and extrapolation of such results to the whole species (to which such reference microorganism belongs) should be performed carefully, if at all. Thus, the question of the exact number of strains required to obtain conclusive data on the type and level of biological effect exerted by the MF remains open. However, the answer should be provided in the first place, taking into consideration the possible advantages of the application of the MF in medical microbiology and biotechnology.

\section{Materials and Methods}

\subsection{Experimental Setup}

A schematic diagram of the experimental setup with the RMF generator is graphically presented in Figure 6. The base of each RMF reactor was a 3-phase, 4-pole stator with an internal core diameter of $16 \mathrm{~cm}$ and a height of $20 \mathrm{~cm}$ equipped with 12 groups of 3 coil sets [54]. The alternating current (AC) frequency supplied to the RMF generator was controlled using a Unidrive M200 inverter (Control Techniques, Nidec Industrial Automation, Poznan, Poland). The temperature in the RMF reactor chamber was maintained using a water-fed cooling/heating system monitored by a set of temperature probes with sampling deviation in the accuracy range $\pm 1.0^{\circ} \mathrm{C}$. The correct temperature distribution in the RMF reactor chamber was ensured by airflow supplied continuously throughout the exposure $\left(2 \mathrm{~L} / \mathrm{min}, 37^{\circ} \mathrm{C}\right.$, RH $60 \%$ ). The characteristics of the RMF, including the distribution of magnetic induction $(B)$ in the reactor chamber, were performed at $100 \mathrm{~V}$ and $\mathrm{AC}$ frequencies of 5 and $50 \mathrm{~Hz}$ using Ansys Maxwell simulation software ver.19.1 (Ansys, Inc., Canonsburg, PA, USA) and confirmed empirically using a teslameter (SMS-102, Asonik, Tuczno, Poland). 


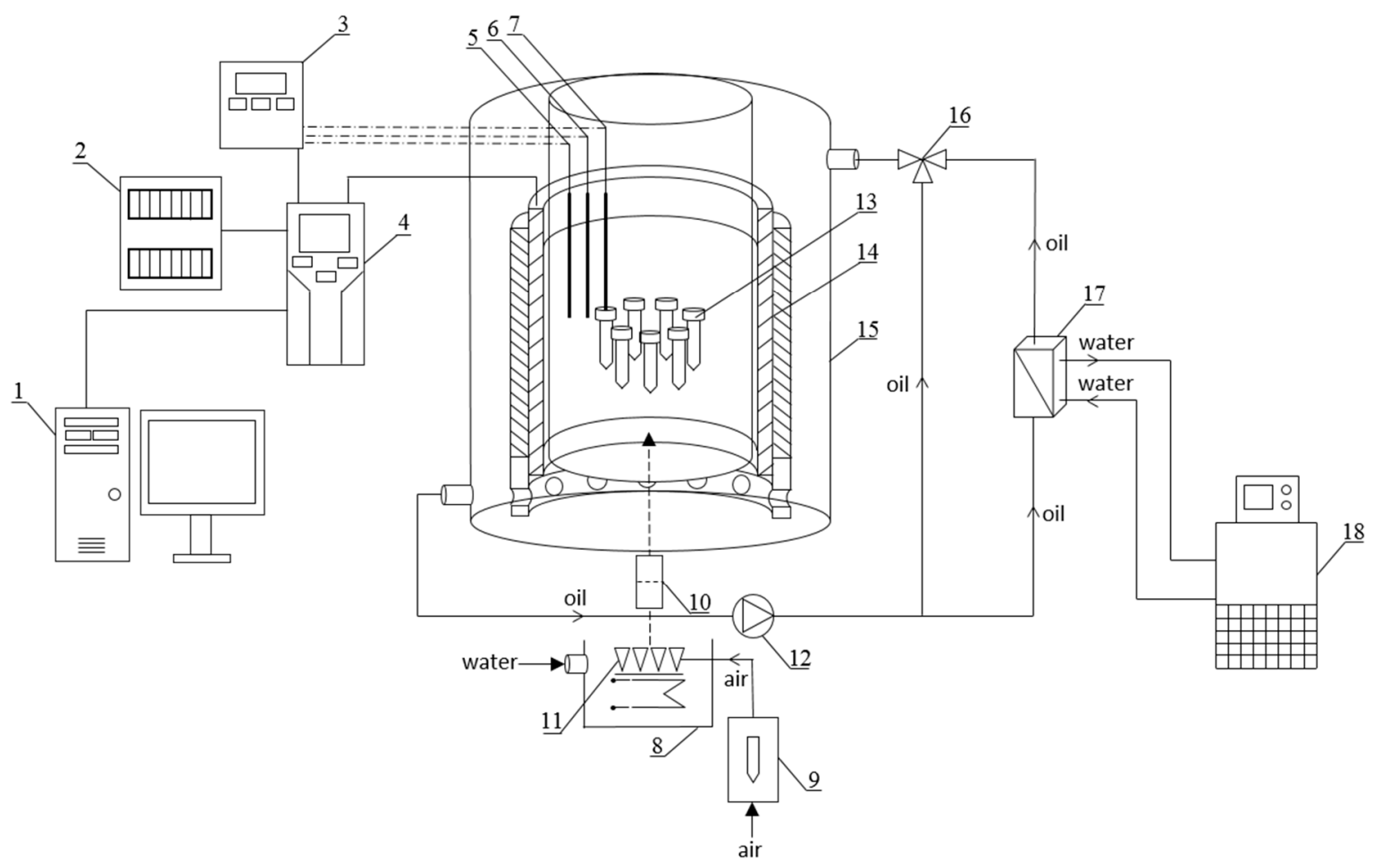

Figure 6. Schematic diagram of the experimental setup with the RMF generator. Experimental setup: 1—computer, 2-electrical switchgear, 3-measuring and control equipment, 4-inverter, 5-temperature probe, 6- $\mathrm{RH} \%$ probe, 7-sample temperature probe, 8-water bath, 9-rotameter, 10-filter, 11-sparger, 12-circulation pump, 13-sample, 14-RMF generator, 15-cooling jacket, 16 -three-way valve, 17-heat exchanger, 18 - thermostat.

\subsection{Microorganisms and Culture Conditions}

Eight species of bacteria, including Staphylococcus aureus, Pseudomonas aeruginosa, Proteus mirabilis, Klebsiella pneumoniae, Enterococcus faecalis, Enterobacter cloacae, Moraxella catarrhalis, and Bacillus cereus, were chosen for experimental purposes. Each species, except for $S$. aureus, was represented by 4 different strains. In the case of $S$. aureus (species chosen for an extended analyses), 8 strains were scrutinized. Moreover, an additional group of S. aureus belonging to a single clonal type but representing different biotypes was also included in the experiment.

Each species group consisted of 1 reference strain and 3 ( 7 in the case of S. aureus) wild isolates. The group of $S$. aureus representing 1 clonal type belonged to the Strain Collection of the Department of Microbiology and Biotechnology of West Pomeranian University of Technology in Szczecin. The results of the genetic and biochemical analyses for this group of microorganisms were already published $[39,55]$. The remaining wild isolates belonged to the Strain Collection of the Department of Pharmaceutical Microbiology and Parasitology of Wroclaw Medical University. Species identification was performed, in the first step by macroscopic observation of specific colonies on Columbia agar (Graso Biotech, Jablowo, Poland). Then, colonies were transferred into Mueller-Hinton agar (M-H, Graso Biotech, Jablowo, Poland) and identified using the Becton-Dickinson Phoenix 100 automated system for microorganism detection (Becton-Dickinson, Franklin Lakes, NJ, USA). The following reference strains were used: Staphylococcus aureus American Type Culture Collection (ATCC 6538), Pseudomonas aeruginosa (ATCC 15442), Proteus mirabilis (ATCC 7002), Klebsiella pneumoniae (ATCC 70603), Enterococcus faecalis (ATCC 29212), Enterobacter cloacae Polish Collection of Microorganisms (PCM) 2569, Moraxella catarrhalis (PCM 2340), and Bacillus cereus (PCM 449).

The species of bacteria chosen for this research were characterized by various shapes, cell wall structures (Gram-negative and Gram-positive), and metabolisms and the ability to move and produce spores (Table 4). 
Table 4. Characteristics of bacterial species selected for the study.

\begin{tabular}{|c|c|c|c|c|c|c|c|}
\hline & $\begin{array}{c}\text { Gram } \\
\text { Staining }\end{array}$ & Shape & Spore & Capsule & Motility & $\begin{array}{l}\text { Catalase/ } \\
\text { Oxidase }\end{array}$ & $\begin{array}{c}\text { Oxidative/ } \\
\text { Fermentative }\end{array}$ \\
\hline S. aureus & + ve & cocci & - ve & - ve & - ve & +ve/-ve & $\mathrm{F}$ \\
\hline P. aeruginosa & - ve & rod & - ve & $-\mathrm{ve}$ & $+v e$ & +ve/+ve & $\mathrm{O}$ \\
\hline P. mirabilis & - ve & rod & - ve & - ve & +ve & +ve/-ve & $\mathrm{F}$ \\
\hline K. pneumoniae & - ve & rod & - ve & $+\mathrm{ve}$ & - ve & $+\mathrm{ve} /-\mathrm{ve}$ & $\mathrm{F}$ \\
\hline E. faecalis & + ve & cocci & - ve & $-\mathrm{ve}$ & - ve & -ve/-ve & $\mathrm{F}$ \\
\hline E. cloacae & - ve & rod & - ve & $-\mathrm{ve}$ & + ve & +ve/-ve & $\mathrm{F}$ \\
\hline M. catarrhalis & + ve & cocci & - ve & +ve & - ve & +ve/+ve & $\mathrm{U}$ \\
\hline B. cereus & + ve & $\begin{array}{c}\text { rod with } \\
\text { square ends }\end{array}$ & $+v e$ & - ve & $+\mathrm{ve}$ & $+/-$ ve & $\mathrm{O}$ \\
\hline
\end{tabular}

U-unreactive (nonsaccharolytic).

The group of S. aureus isolates was additionally analyzed according to the biochemical features using VITEK ${ }^{\circledR} 2$ Compact (bioMérieux, Durham, NC, USA) and genetic diversity using the pulsed-field gel electrophoresis (PFGE) method (Bio-Rad Laboratories, Inc., Hercules, CA, USA).

\subsection{Exposure of Bacterial Cultures to the RMF}

Initially, bacterial strains were plated on Brain Heart Infusion Agar (Graso Biotech, Jablowo, Poland) and cultivated for $24 \mathrm{~h}$ at $37^{\circ} \mathrm{C}$. After incubation, one colony-forming unit (CFU) of each isolate was transferred into $10 \mathrm{~mL}$ of Tryptic Soy Broth (TSB, Oxoid, Basingstoke, UK) and incubated for $24 \mathrm{~h}$ at $37^{\circ} \mathrm{C}$ with shaking. In the next step, cultures (1.0 in McFarland turbidity standard) were diluted 1:10 in TSB. The obtained bacterial suspensions were vortexed and dispensed at a volume of $10 \mathrm{~mL}$ into $15 \mathrm{~mL}$ plastic tubes with caps featuring seven holes and a specific capillary pore filter membrane with a pore size of $0.2 \mu \mathrm{m}$ providing gas exchange (CELLSTAR ${ }^{\circledR}$ CELLreactor $^{\mathrm{TM}}$, Greiner Bio-One $\mathrm{GmbH}$, Frickenhausen, Germany) in which the bacteria were exposed to the RMF.

The bacteria were exposed to the RMF generated at different AC frequencies $(5$ and $50 \mathrm{~Hz})$ for $9 \mathrm{~h}$. The test tubes with bacterial cultures were arranged in the RMF generator in a way that allowed the same exposure to the RMF of the whole volume of bacterial culture (Figure 7a,b).

(a)

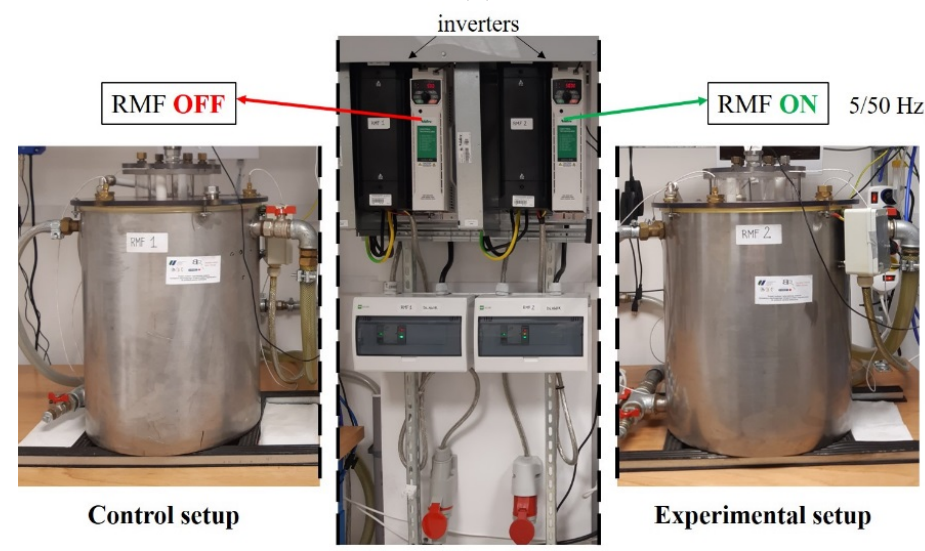

(b)

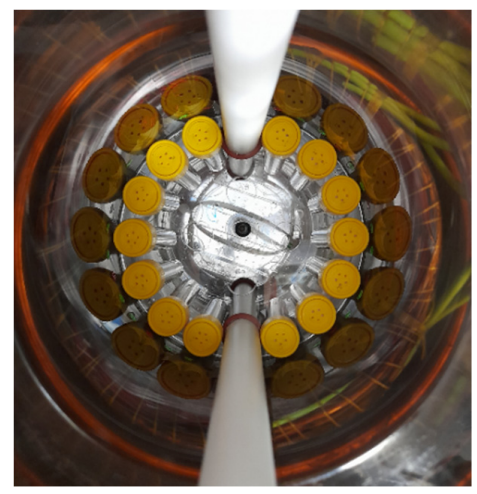

Figure 7. (a) The RMF generator and control settings with monitoring and control equipment. (b) Arrangement and location of the tubes with bacterial cultures inside the RMF generator.

The same bacteria incubated at the same time and under the same conditions as during the experiment but without exposure to the RMF were used as positive controls (RMF-off controls). The RMF-off controls were incubated in the twin reactor, however, with the RMF generator switched off (Figure 7a). As it was recorded, the fluctuations of the 
temperature during the incubation of controls were the same as recorded during exposure of bacteria to the RMF and were less than $1.0^{\circ} \mathrm{C}$. The control RMF-off reactor was placed $2 \mathrm{~m}$ from the reactor with the RMF generator on. As measured using a Hall probe (Smart Magnetic Sensor-102, Asonik, Tuczno, Poland), the source of the RMF did not affect the RMF-off controls during the experiment (the magnetic induction in the RMF controls $(B)$ was $\leq 0.05 \mathrm{mT})$.

\subsection{Growth Dynamics and Metabolic Activity of Bacterial Cells}

The optical density (OD) of bacterial cultures, which indirectly reflects cellular growth, was measured using an Infinite 200 PRO NanoQuant Microplate Reader (Tecan Trading AG, Männedorf, Switzerland) at a wavelength of $600 \mathrm{~nm}$ in 96-well plates (NEST Biotechnology Co., Ltd., Wuxi, Jiangsu, China) with $100 \mu \mathrm{L}$ of each sample of bacterial culture taken after 3,6 , and $9 \mathrm{~h}$ of exposure to the RMF ( 5 and $50 \mathrm{~Hz}$ ).

The metabolic activity of bacterial cells was determined using Alamar-Blue Cell Viability assay (Thermo Fisher, Eugene, OR, USA). Alamar-Blue Cell Viability Reagent is a ready-to-use resazurin-based solution that functions as a cell viability and metabolic activity indicator. Resazurin, the active ingredient of Alamar-Blue Reagent, is a nontoxic, cell-permeable compound that is blue in color and virtually nonfluorescent. Upon entering living cells, resazurin is reduced to resorufin, a compound that is red in color and highly fluorescent. After 3, 6, and $9 \mathrm{~h}$ of exposure to the RMF ( 5 and $50 \mathrm{~Hz}$ ), $100 \mu \mathrm{L}$ of each bacterial culture was transferred into wells of 96-well fluorescence microtiter plates (Greiner BioOne GmbH, Frickenhausen, Germany). Next, $10 \mu \mathrm{L}$ of Alamar-Blue was added, and the plates were incubated for $30 \mathrm{~min}$ at $37^{\circ} \mathrm{C}$ in the dark. Fluorescence was measured using a microplate fluorescence reader (Synergy HTX, BioTek, Winooski, VT, USA) at wavelengths of 540 and $590 \mathrm{~nm}$ for excitation and emission, respectively. As a blank, sterile TSB was used.

The results for both aforementioned assays were shown as the percentage of control values calculated using Equation (1):

$$
\% \text { of control }=\left(\mathrm{A}_{\text {sample }}-\mathrm{A}_{\text {background }}\right) /\left(\mathrm{A}_{\text {positive control }}-\mathrm{A}_{\text {background }}\right) \times 100
$$

where $\mathrm{A}$ is absorbance.

\subsection{Analysis of Molecular Diversity between Strains of S. aureus}

The genetic relationship between the examined isolates was analyzed by digestion of chromosomal DNA with SmaI enzyme and its separation by pulsed-field gel electrophoresis (PFGE) method, according to the manufacturer of the GenePath Group 6 Reagent Kit Instruction Manual (Bio-Rad Laboratories, Inc., Marnes-la-Coquette, France) and the Centers for Disease Control and Prevention (CDC) protocol (oxacillinresistant Staphylococcus aureus on PulseNet (OPN)), laboratory protocol for molecular typing of $S$. aureus to pulsed-field gel electrophoresis (PFGE) [56].

Single colonies of S. aureus isolates (Graso Biotech, Jablowo, Poland) were transferred from blood agar plates to $3 \mathrm{~mL}$ of Tryptone Soya Broth (TSB, Oxoid, Basingstoke, UK) and incubated for $24 \mathrm{~h}$ at $37^{\circ} \mathrm{C}$. Next, $1 \mathrm{~mL}$ cultures were transferred to $1.5 \mathrm{~mL}$ tubes and centrifuged at $5000 \mathrm{rpm}$ for $5 \mathrm{~min}$, and the resulting cell pellets were mixed with Cell Suspension Buffer $(100 \mu \mathrm{L}), 6 \mu \mathrm{L}$ of lysozyme $(0.025 \mathrm{~g} / \mathrm{mL}$, Millipore Sigma, Mannheim, Germany), $4 \mu \mathrm{L}$ of lysostaphin (400 U/mL, DNA Gdansk, Gdansk, Poland), and $100 \mu \mathrm{L}$ of $2 \%$, warmed to $55^{\circ} \mathrm{C}$, liquid agarose solution (Bio-Rad Laboratories, Inc., Marnes-laCoquette, France) and transferred into molds to form blocks, which were further treated with $20 \mu \mathrm{L}$ of proteinase K (DNA Gdańsk, Gdansk, Poland) in Proteinase K Buffer, and digested with $3 \mu \mathrm{L}$ of the restriction enzyme SmaI in Tango Buffer (Thermo Fisher Scientific, Hennigsdorf, Germany). The above-mentioned steps were carried out separately in two replications for each of the test strains of $S$. aureus.

The plugs were loaded into $1.2 \%$ agarose gels and electrophoresed in TBE buffer (InnoTrain Diagnostik GmbH, Kronberg, Germany) using a CHEF-DR III apparatus (Bio-Rad 
Laboratories, Inc., Marnes-la-Coquette, France). The run time was $22 \mathrm{~h}$ with an initial switch time of $2.2 \mathrm{~s}$ and a final switch time of $54.2 \mathrm{~s}$. The ramping factor was linear. The temperature was set at $14{ }^{\circ} \mathrm{C}$, voltage at $6 \mathrm{~V} / \mathrm{cm}$, and the included angle at $120^{\circ}$. The gels were stained with ethidium bromide $(0.5 \mu \mathrm{g} / \mathrm{mL}$, Mannheim, Germany) and photographed in an image system, GelDoc-It2 Imager (Upland, CA, USA). Restriction profiles were analyzed using the FPQuest software (Bio-Rad Laboratories, Inc., Marnes-la-Coquette, France). The classification of individual restriction patterns for particular genetic profiles was made using the unweighted pair group method with the arithmetic mean (UPGMA) method (similarity coefficient $(\mathrm{SAB})$ value $=65.7 \%$ ) and the Dice coefficient $(2.0 \%)$. The results are presented in the form of a dendrogram.

\subsection{Statistical Analysis}

Data are presented as the means \pm standard errors of the means (SEM) calculated from three repetitions of the experiment (plus three technical repetitions for each measurement). The statistical significance of the differences between RMF-exposed and control cultures, cultures exposed or incubated for different time, cultures of different strains, and cultures exposed to the RMF at 5 and $50 \mathrm{~Hz}$ was analyzed by two-way analysis of variance (ANOVA) and Tukey's post hoc test. Differences were considered significant at a level of $p<0.05$. The statistical analyses were conducted using Statistica 12.5 (StatSoft, Inc., Tulsa, OK, USA).

\section{Conclusions}

In conclusion, our research has proven that, apart from the previously described factors related primarily to the characteristics of the magnetic field, one of the key parameters affecting the final result of its influence is the specificity of a given microorganism. By the specificity of a microorganism we mean not only the species, cell shape, or cell wall structure, but also the individual set of features specific for the given strain, referred to as the intraspecies variability. We showed that, depending on the exposed strain, the effect exerted by the RMF may be positive (i.e., manifests as the increase in growth rate or/and cellular metabolic activity) or negative (e.g., manifests as the reduction of both aforementioned features) or none. Therefore, the data from the performed analyses explicitly show that biological effects exerted by the magnetic field on a single strain (reference or wild type) cannot be extrapolated to the entire bacterial species this specific analyzed strain belongs to.

Supplementary Materials: The following are available online at https: / /www.mdpi.com/article/ 10.3390/pathogens10111427/s1: Table S1: Phenotypic patterns of S. aureus strains; Table S2: Statistical differences in growth dynamics between $S$. aureus strains representing different clonal types exposed for $3 \mathrm{~h}$ to a rotating magnetic field of $5 \mathrm{~Hz}$; Table S3: Statistical differences in growth dynamics between $S$. aureus strains representing different clonal types exposed for $6 \mathrm{~h}$ to a rotating magnetic field of $5 \mathrm{~Hz}$; Table S4: Statistical differences in growth dynamics between S. aureus strains representing different clonal types exposed for $9 \mathrm{~h}$ to a rotating magnetic field of $5 \mathrm{~Hz}$; Table S5: Statistical differences in growth dynamics of $S$. aureus strains representing different clonal types depending on the duration $(3,6$, and $9 \mathrm{~h}$ ) of rotating magnetic field $(5 \mathrm{~Hz})$ exposure; Table S6: Statistical differences in growth dynamics between $S$. aureus strains representing different clonal types exposed for $3 \mathrm{~h}$ to a rotating magnetic field of $50 \mathrm{~Hz}$; Table S7: Statistical differences in growth dynamics between S. aureus strains representing different clonal types exposed for $6 \mathrm{~h}$ to a rotating magnetic field of $50 \mathrm{~Hz}$; Table S8: Statistical differences in growth dynamics between S. aureus strains representing different clonal types exposed for $9 \mathrm{~h}$ to a rotating magnetic field of $50 \mathrm{~Hz}$; Table S9: Statistical differences in growth dynamics of $S$. aureus strains representing different clonal types depending on the duration $(3,6$, and $9 \mathrm{~h}$ ) of rotating magnetic field $(50 \mathrm{~Hz})$ exposure; Table S10: Statistical differences in growth dynamics of $S$. aureus strains representing different clonal types exposed to a rotating magnetic field ( 5 vs. $50 \mathrm{~Hz}$ ); Table S11: Statistical differences in cellular metabolic activity between $S$. aureus strains representing different clonal types exposed for $3 \mathrm{~h}$ to a rotating magnetic field of $5 \mathrm{~Hz}$; Table S12: Statistical differences in cellular metabolic activity between S. aureus strains representing different clonal types exposed for $6 \mathrm{~h}$ to a rotating magnetic field of $5 \mathrm{~Hz}$; Table S13: 
Statistical differences in cellular metabolic activity between $S$. aureus strains representing different clonal types exposed for $9 \mathrm{~h}$ to a rotating magnetic field of $5 \mathrm{~Hz}$; Table S14: Statistical differences in cellular metabolic activity of $S$. aureus strains representing different clonal types depending on the duration $(3,6$, and $9 \mathrm{~h})$ of rotating magnetic field $(5 \mathrm{~Hz})$ exposure; Table S15: Statistical differences in cellular metabolic activity between $S$. aureus strains representing different clonal types exposed for $3 \mathrm{~h}$ to a rotating magnetic field of $50 \mathrm{~Hz}$; Table S16: Statistical differences in cellular metabolic activity between $S$. aureus strains representing different clonal types exposed for $6 \mathrm{~h}$ to a rotating magnetic field of $50 \mathrm{~Hz}$; Table S17: Statistical differences in cellular metabolic activity between S. aureus strains representing different clonal types exposed for $9 \mathrm{~h}$ to a rotating magnetic field of $50 \mathrm{~Hz}$; Table S18: Statistical differences in cellular metabolic activity of $S$. aureus strains representing different clonal types depending on the duration $(3,6$, and $9 \mathrm{~h})$ of rotating magnetic field $(50 \mathrm{~Hz})$ exposure; Table S19: Statistical differences in cellular metabolic activity of $S$. aureus strains representing different clonal types exposed to a rotating magnetic field ( 5 vs. $50 \mathrm{~Hz}$ ); Table S20: The values of magnetic induction inside the RMF generator, at the location of the Petri dishes, depending on the applied AC frequency; Figure S1: Statistical differences in growth dynamics and cellular metabolic activity between S. aureus strains representing one clonal type exposed to a rotating magnetic field ( 5 and $50 \mathrm{~Hz}$ ) for 3,6 , and 9 h; Figure S2: Statistical differences in growth dynamics and cellular metabolic activity between P. aeruginosa strains exposed to a rotating magnetic field ( 5 and $50 \mathrm{~Hz}$ ) for 3, 6, and $9 \mathrm{~h}$; Figure S3: Statistical differences in growth dynamics and cellular metabolic activity between $E$. faecalis strains exposed to a rotating magnetic field $(5$ and $50 \mathrm{~Hz}$ ) for 3, 6, and 9 h; Figure S4: Statistical differences in growth dynamics and cellular metabolic activity between $E$. cloacae strains exposed to a rotating magnetic field (5 and $50 \mathrm{~Hz}$ ) for 3, 6, and 9 h; Figure S5: Statistical differences in growth dynamics and cellular metabolic activity between $K$. pneumoniae strains exposed to a rotating magnetic field ( 5 and $50 \mathrm{~Hz}$ ) for 3, 6, and $9 \mathrm{~h}$; Figure S6: Statistical differences in growth dynamics and cellular metabolic activity between $B$. cereus strains exposed to a rotating magnetic field ( 5 and $50 \mathrm{~Hz}$ ) for 3, 6, and 9 h; Figure S7: Statistical differences in growth dynamics and cellular metabolic activity between P. mirabilis strains exposed to a rotating magnetic field ( 5 and $50 \mathrm{~Hz}$ ) for 3, 6, and $9 \mathrm{~h}$; Figure S8: Statistical differences in growth dynamics and cellular metabolic activity between $M$. catarrhalis strains exposed to a rotating magnetic field ( 5 and $50 \mathrm{~Hz}$ ) for 3, 6, and $9 \mathrm{~h}$.

Author Contributions: Conceptualization, K.F. and M.W. (Marta Woroszyło); methodology, K.F., M.W. (Marta Woroszyło) and A.J.; formal analysis, K.F. and A.J.; investigation, M.W. (Marta Woroszyło), D.C.-J., A.J., A.P. and P.K.; resources, A.J.; data curation, K.F.; writing-original draft preparation, K.F. and M.W. (Marta Woroszyło); writing-review and editing, K.F. and A.J.; visualization, M.W. (Marta Woroszyło), D.C.-J. and M.W. (Marcin Wardach); supervision, K.F.; project administration, K.F.; funding acquisition, K.F. All authors have read and agreed to the published version of the manuscript.

Funding: This research was funded by the National Science Centre (Grant No. 2017/27/B/NZ6/02103).

Institutional Review Board Statement: Not applicable.

Informed Consent Statement: Not applicable.

Data Availability Statement: The data presented in this study are available on request from the corresponding author.

Conflicts of Interest: The authors declare no conflict of interest.

\section{References}

1. Redlarski, G.; Lewczuk, B.; Żak, A.; Koncicki, A.; Krawczuk, M.; Piechocki, J.; Jakubiuk, K.; Tojza, P.; Jaworski, J.; Ambroziak, D.; et al. The influence of electromagnetic pollution on living organisms: Historical trends and forecasting changes. BioMed Res. Int. 2015, 2015, 234098. [CrossRef] [PubMed]

2. Finn, R.K.; Halvorson, H.O.; Sadoff, H.L. Electrolysis as a means of aerating submerged cultures of microorganisms. Appl. Microbiol. 1956, 4, 164-170. [CrossRef] [PubMed]

3. Sale, A.; Hamilton, W. Effects of high electric fields on microorganismsI. Killing of bacteria and yeasts. Biochim. Biophys. Acta (BBA)-Gen. Subj. 1967, 148, 781-788. [CrossRef]

4. Sale, A.; Hamilton, W.A. Effects of high electric fields on micro-organisms. Biochim. Biophys. Acta (BBA)-Biomembr. 1968, 163, 37-43. [CrossRef]

5. Grosman, Z.; Kolár, M.; Tesaríková, E. Effects of static magnetic field on some pathogenic microorganisms. Acta Univ. Palacki. Olomuc. Fac. Med. 1992, 134, 7-9. [PubMed] 
6. Kohno, M.; Yamazaki, M.; Kimura, I.; Wada, M. Effect of static magnetic fields on bacteria: Streptococcus mutans, Staphylococcus aureus, and Escherichia coli. Pathophysiology 2000, 7, 143-148. [CrossRef]

7. Fojt, L.; Strašák, L.; Vetterl, V.; Šmarda, J. Comparison of the low-frequency magnetic field effects on bacteria Escherichia coli, Leclercia adecarboxylata and Staphylococcus aureus. Bioelectrochemistry 2004, 63, 337-341. [CrossRef]

8. Potenza, L.; Ubaldi, L.; Sanctis, R.; de Bellis, R.; de Cucchiarini, L.; Dachà, M. Effects of a static magnetic field on cell growth and gene expression in Escherichia coli. Mutat. Res. 2004, 561, 53-62. [CrossRef]

9. Kermanshahi, R.K.; Sailani, M.R. Effect of static electric field treatment on multiple antibiotic-resistant pathogenic strains of Escherichia coli and Staphylococcus aureus. J. Microbiol. Immunol. Infect. 2005, 38, 394-398.

10. Strašák, L.; Vetterl, V.; Fojt, L. Effects of $50 \mathrm{~Hz}$ Magnetic Fields on the Viability of Different Bacterial Strains. Electrom. Biol. Med. 2005, 24, 293-300. [CrossRef]

11. Obermeier, A.; Matl, F.D.; Friess, W.; Stemberger, A. Growth inhibition of Staphylococcus aureus induced by low-frequency electric and electromagnetic fields. Bioelectromagnetics 2009, 30, 270-279. [CrossRef] [PubMed]

12. László, J.; Kutasi, J. Static magnetic field exposure fails to affect the viability of different bacteria strains. Bioelectromagnetics 2010, 31, 220-225. [CrossRef] [PubMed]

13. Inhan-Garip, A.; Aksu, B.; Akan, Z.; Akakin, D.; Ozaydin, A.N.; San, T. Effect of extremely low frequency electromagnetic fields on growth rate and morphology of bacteria. Int. J. Radiat. Biol. 2011, 87, 1155-1161. [CrossRef]

14. Bajpai, I.; Saha, N.; Basu, B. Moderate intensity static magnetic field has bactericidal effect on E. coli and S. epidermidis on sintered hydroxyapatite. J. Biomed. Mater. Res. 2012, 100, 1206-1217. [CrossRef] [PubMed]

15. Filipič, J.; Kraigher, B.; Tepuš, B.; Kokol, V.; Mandic-Mulec, I. Effects of low-density static magnetic fields on the growth and activities of wastewater bacteria Escherichia coli and Pseudomonas putida. Bioresour. Technol. 2012, 120, 225-232. [CrossRef]

16. Segatore, B.; Setacci, D.; Bennato, F.; Cardigno, R.; Amicosante, G.; Iorio, R. Evaluations of the effects of extremely low-frequency electromagnetic fields on growth and antibiotic susceptibility of Escherichia coli and Pseudomonas aeruginosa. Int. J. Microbiol. 2012, 2012, 587293. [CrossRef] [PubMed]

17. Fijalkowski, K.; Nawrotek, P.; Struk, M.; Kordas, M.; Rakoczy, R. The effects of rotating magnetic field on growth rate, cell metabolic activity and biofilm formation by Staphylococcus aureus and Escherichia coli. J. Magn. 2013, 18, 289-296. [CrossRef]

18. Nawrotek, P.; Fijałkowski, K.; Struk, M.; Kordas, M.; Rakoczy, R. Effects of $50 \mathrm{~Hz}$ rotating magnetic field on the viability of Escherichia coli and Staphylococcus aureus. Electrom. Biol. Med. 2014, 33, 29-34. [CrossRef] [PubMed]

19. Bayır, E.; Bilgi, E.; Şendemir-Ürkmez, A.; Hameş-Kocabaş, E.E. The effects of different intensities, frequencies and exposure times of extremely low-frequency electromagnetic fields on the growth of Staphylococcus aureus and Escherichia coli O157:H7. Electrom. Biol. Med. 2015, 34, 14-18. [CrossRef]

20. Fijałkowski, K.; Nawrotek, P.; Struk, M.; Kordas, M.; Rakoczy, R. Effects of rotating magnetic field exposure on the functional parameters of different species of bacteria. Electrom. Biol. Med. 2015, 34, 48-55. [CrossRef] [PubMed]

21. Tessaro, L.W.E.; Murugan, N.J.; Persinger, M.A. Bacterial growth rates are influenced by cellular characteristics of individual species when immersed in electromagnetic fields. Microbiol. Res. 2015, 172, 26-33. [CrossRef]

22. Mousavian-Roshanzamir, S.; Makhdoumi-Kakhki, A. The inhibitory effects of static magnetic field on Escherichia coli from two different sources at short exposure time. Rep. Biochem. Mol. Biol. 2017, 5, 112-116.

23. Salmen, S.H.; Alharbi, S.A.; Faden, A.A.; Wainwright, M. Evaluation of effect of high frequency electromagnetic field on growth and antibiotic sensitivity of bacteria. Saudi J. Biol. Sci. 2018, 25, 105-110. [CrossRef] [PubMed]

24. Konopacki, M.; Rakoczy, R. The analysis of rotating magnetic field as a trigger of Gram-positive and Gram-negative bacteria growth. Biochem. Eng. J. 2019, 141, 259-267. [CrossRef]

25. Masood, S.; Saleem, I.; Smith, D.; Chu, W.-K. Growth pattern of magnetic field-treated bacteria. Curr. Microbiol. 2020, 77, 194-203. [CrossRef]

26. Piatti, E.; Cristina Albertini, M.; Baffone, W.; Fraternale, D.; Citterio, B.; Piera Piacentini, M.; Dachà, M.; Vetrano, F.; Accorsi, A. Antibacterial effect of a magnetic field on Serratia marcescens and related virulence to Hordeum vulgare and Rubus fruticosus callus cells. Comp. Biochem. Physiol. B Biochem. Mol. Biol. 2002, 132, 359-365. [CrossRef]

27. Strašák, L.; Vetterl, V.; Šmarda, J. Effects of low-frequency magnetic fields on bacteria Escherichia coli. Bioelectrochemistry 2002, 55, 161-164. [CrossRef]

28. Gao, W.; Liu, Y.; Zhou, J.; Pan, H. Effects of a strong static magnetic field on bacterium Shewanella oneidensis: An assessment by using whole genome microarray. Bioelectromagnetics 2005, 26, 558-563. [CrossRef] [PubMed]

29. Poortinga, A.T.; Bos, R.; Busscher, H.J. Lack of effect of an externally applied electric field on bacterial adhesion to glass. Colloids Surf. B Biointerfaces 2001, 20, 189-194. [CrossRef]

30. Babushkina, I.V.; Borodulin, V.B.; Shmetkova, N.A.; Morrison, V.V.; Usanov, A.D.; Skripal', A.V.; Usanov, D.A. The influence of alternating magnetic field on Escherichia coli bacterial cells. Pharm. Chem. J. 2005, 39, 398-400. [CrossRef]

31. Justo, O.R.; Pérez, V.H.; Alvarez, D.C.; Alegre, R.M. Growth of Escherichia coli under extremely low-frequency electromagnetic fields. Appl. Biochem. Biotechnol. 2006, 134, 155-164. [CrossRef]

32. Cellini, L.; Grande, R.; Di Campli, E.; Di Bartolomeo, S.; Di Giulio, M.; Robuffo, I.; Trubiani, O.; Mariggiò, M.A. Bacterial response to the exposure of $50 \mathrm{~Hz}$ electromagnetic fields. Bioelectromagnetics 2008, 29, 302-311. [CrossRef]

33. Dunca, S.; Creanga, D.-E.; Ailiesei, O.; Nimitan, E. Microorganisms growth with magnetic fluids. J. Magn. Magn. Mater. 2005, 289, 445-447. [CrossRef] 
34. Hu, X.; Qiu, Z.; Wang, Y.; She, Z.; Qian, G.; Ren, Z. Effect of ultra-strong static magnetic field on bacteria: Application of Fourier-transform infrared spectroscopy combined with cluster analysis and deconvolution. Bioelectromagnetics 2009, 30, 500-507. [CrossRef] [PubMed]

35. Violle, C.; Enquist, B.J.; McGill, B.J.; Jiang, L.; Albert, C.H.; Hulshof, C.; Jung, V.; Messier, J. The return of the variance: Intraspecific variability in community ecology. Trends Ecol. Evol. 2012, 27, 244-252. [CrossRef]

36. Dijkshoorn, L.; Ursing, B.M.; Ursing, J.B. Strain, clone and species: Comments on three basic concepts of bacteriology. J. Med Microbiol. 2000, 49, 397-401. [CrossRef]

37. Tenover, F.C.; Arbeit, R.D.; Goering, R.V.; Mickelsen, P.A.; Murray, B.E.; Persing, D.H.; Swaminathan, B. Interpreting chromosomal DNA restriction patterns produced by pulsed-field gel electrophoresis: Criteria for bacterial strain typing. J. Clin. Microbiol. 1995, 33, 2233-2239. [CrossRef]

38. Martínez-Carranza, E.; Barajas, H.; Alcaraz, L.-D.; Servín-González, L.; Ponce-Soto, G.-Y.; Soberón-Chávez, G. Variability of Bacterial Essential Genes Among Closely Related Bacteria: The case of Escherichia coli. Front. Microbiol. 2018, 9, 1059. [CrossRef]

39. Nawrotek, P.; Czernomysy-Furowicz, D.; Borkowski, J.; Fijałkowski, K.; Pobucewicz, A. The effect of auto-vaccination therapy on the phenotypic variation of one clonal type of Staphylococcus aureus isolated from cows with mastitis. Vet. Microbiol. 2012, 155, 434-437. [CrossRef]

40. Valle, A.; Zanardini, E.; Abbruscato, P.; Argenzio, P.; Lustrato, G.; Ranalli, G.; Sorlini, C. Effects of low electric current (LEC) treatment on pure bacterial cultures. J. Appl. Microbiol. 2007, 103, 1376-1385. [CrossRef]

41. European Committee on Antimicrobial Susceptibility Testing. Available online: https:/ / eucast.org/ (accessed on 28 February 2021).

42. Clinical and Laboratory Standards Institute. Available online: https:/ / clsi.org/ (accessed on 28 February 2021).

43. Kong, H.; Yu, F.; Zhang, W.; Li, X.; Wang, H. Molecular epidemiology and antibiotic resistance profiles of methicillin-resistant Staphylococcus aureus strains in a tertiary hospital in China. Front. Microbiol. 2017, 8, 838. [CrossRef]

44. Meroni, G.; Soares Filipe, J.F.; Drago, L.; Martino, P.A. Investigation on antibiotic-resistance, biofilm formation and virulence factors in multi drug resistant and non multi drug resistant Staphylococcus pseudintermedius. Microorganisms 2019, 7, 702. [CrossRef]

45. Mulyukin, A.L.; Suzina, N.E.; Mel'nikov, V.G.; Gal'chenko, V.F.; El'-Registan, G.I. Dormant state and phenotypic variability of Staphylococcus aureus and Corynebacterium pseudodiphtheriticum. Microbiology 2014, 83, 149-159. [CrossRef]

46. Libberton, B.; Coates, R.E.; Brockhurst, M.A.; Horsburgh, M.J. Evidence that intraspecific trait variation among nasal bacteria shapes the distribution of Staphylococcus aureus. Infect. Immun. 2014, 82, 3811-3815. [CrossRef]

47. van Gestel, J.; Bareia, T.; Tenennbaum, B.; Dal Co, A.; Guler, P.; Aframian, N.; Puyesky, S.; Grinberg, I.; D'Souza, G.G.; Erez, Z.; et al. Short-range quorum sensing controls horizontal gene transfer at micron scale in bacterial communities. Nat. Commun. 2021, 12, 2324. [CrossRef]

48. Suresh, S.; Alva, P.P.; Premanath, R. Modulation of quorum sensing-associated virulence in bacteria: Carbohydrate as a key factor. Arch. Microbiol. 2021, 203, 1881-1890. [CrossRef]

49. Pisithkul, T.; Schroeder, J.W.; Trujillo, E.A.; Yeesin, P.; Stevenson, D.M.; Chaiamarit, T.; Coon, J.J.; Wang, J.D.; Amador-Noguez, D. Metabolic Remodeling during biofilm development of Bacillus subtilis. MBio 2019, 10, e00623-19. [CrossRef]

50. Waite, A.J.; Frankel, N.W.; Emonet, T. Behavioral variability and phenotypic diversity in bacterial chemotaxis. Annu. Rev. Biophys. 2018, 47, 595-616. [CrossRef]

51. Magana, M.; Sereti, C.; Ioannidis, A.; Mitchell, C.A.; Ball, A.R.; Magiorkinis, E.; Chatzipanagiotou, S.; Hamblin, M.R.; Hadjifrangiskou, M.; Tegos, G.P. Options and limitations in clinical investigation of bacterial biofilms. Clin. Microbiol. Rev. 2018, 31, e00084-16. [CrossRef]

52. Luze, H.; Holzer, J.; Nischwitz, S.P.; Kamolz, L.-P. The importance of in vivo biofilm models for clinical practice. Wound Repair Regen. 2020, 28, 578-579. [CrossRef]

53. Maillard, J.-Y.; Kampf, G.; Cooper, R. Antimicrobial stewardship of antiseptics that are pertinent to wounds: The need for a united approach. JAC Antimicrob. Resist. 2021, 3, dlab027. [CrossRef] [PubMed]

54. Drozd, R.; Szymańska, M.; Żywicka, A.; Kowalska, U.; Rakoczy, R.; Kordas, M.; Konopacki, M.; Junka, A.F.; Fijałkowski, K. Exposure to non-continuous rotating magnetic field induces metabolic strain-specific response of Komagataeibacter xylinus. Biochem. Eng. J. 2021, 166, 107855. [CrossRef]

55. Fijałkowski, K.; Masiuk, H.; Czernomysy-Furowicz, D.; Karakulska, J.; Nawrotek, P.; Paszkowska, A.; Struk, M.; Giedrys-Kalemba, S. Superantigen gene profiles, genetic relatedness and biological activity of exosecretions of Staphylococcus aureus isolates obtained from milk of cows with clinical mastitis. Microbiol. Immunol. 2013, 57, 674-683. [CrossRef] [PubMed]

56. Centers for Disease Control and Prevention. Available online: www.cdc.gov (accessed on 30 August 2021). 